\title{
Livelihoods characterization of a small-scale fishing community in the Colombian Caribbean (Colombian Caribbean SSF livelihoods)
}

\author{
Jorge H. Maldonado*, Rocío del Pilar Moreno-Sánchez, Myriam Elizabeth Vargas-Morales and \\ EMILIO LEGUízAMO
}

Departamento de Economía, Universidad de los Andes, Calle 19A No 1-37 Este, Bloque W, Of W-814, 111711 - Bogotá, Colombia; romoreno@uniandes.edu.co (RDPMS), me.vargas374@uniandes.edu.co (MEVM), s.leguizamo10@uniandes.edu.co (EM). ORCID Jorge H. Maldonado (D) https://orcid.org/0000-0001-5501-6374, Rocio del Pilar Moreno-Sánchez (D) https://orcid.org/0000-0002-2817-7399, Myriam Elizabeth Vargas-Morales (D) https://orcid.org/0000-0002-3380-3542, Emilio Leguizamo (D) https://orcid.org/0000-0002-1272-3543

Marine and

Fishery Sciences

MAFIS

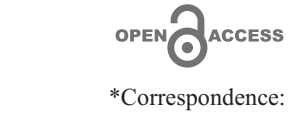

jmaldona@uniandes.edu.co

Received: 3 December 2021

Accepted: 9 February 2022

ISSN 2683-7595 (print) ISSN 2683-7951 (online)

https://ojs.inidep.edu.ar

Journal of the Instituto Nacional de Investigación y Desarrollo Pesquero (INIDEP) Commons under a Creative
CommibutionNonCommercial-ShareAlike 4.0 International License
ABSTRACT. Coastal communities depending on small-scale fisheries (SSFs) are poorly understood. Designing policies to address their vulnerabilities requires understanding the socioeconomic context in which SSFs operate. Unfortunately, that information is usually incomplete in developing countries. This study seeks to close this gap by examining the socio-demographics, assets, livelihood strategies, food security, and poverty levels of both fishing and non-fishing households in a fishing village in the Colombian Caribbean. The analysis follows the sustainable livelihoods approach. Our results show that: (i) SSFs play a double role in fishing households: self-consumption and income generation; (ii) SSFs play an essential role in food security for both fishing and non-fishing households; (iii) livelihood diversification, including multispecies fishing and activities by household members in addition to the head, is key for diversifying risk and smoothing consumption; (iv) fishing communities face significant restrictions in access to financial markets; and (v) although fishing households earn more income than non-fishing ones, they exhibit lower education and literacy. These results show that SSF is a buffer against the vulnerability of fishing communities. Strict conservation strategies might be necessary to sustain SSF, but these must be accompanied by alternative income sources, such as compensation schemes, social protection, or policies enabling alternative livelihoods. JEL Codes: D13, I21, J22, J46, Q22, Q56.

Key words: Sustainable Livelihoods Approach (SLA), small-scale fisheries, assets, poverty, education gap, food security, Colombia.

Caracterización de los medios de vida de una comunidad de pescadores a pequeña escala en el Caribe colombiano (medios de vida de PPE del Caribe colombiano)

RESUMEN. Las comunidades costeras que dependen de la pesca en pequeña escala (PPE) son poco conocidas. El diseño de políticas para abordar sus vulnerabilidades requiere comprender el contexto socioeconómico en el que operan los PPE. Desafortunadamente, esa información suele ser incompleta en los países en desarrollo. Este estudio busca cerrar esta brecha examinando la sociodemografía, los activos, las estrategias de sus medios de vida, la seguridad alimentaria y los niveles de pobreza de los hogares pescadores y no pescadores en una comunidad de pescadores en el Caribe colombiano. El análisis sigue el enfoque de los medios de vida sostenibles. Nuestros resultados muestran que: (i) los PPE juegan un doble papel en los hogares pesqueros: autoconsumo y generación de ingresos; (ii) los PPE juegan un papel esencial en la seguridad alimentaria tanto para los hogares pescadores como para los que no lo son; (iii) la diversificación de los medios de vida, incluida la pesca multiespecífica y las actividades de los miembros del hogar, además del cabeza de 
familia, es clave para diversificar el riesgo y suavizar el consumo; (iv) las comunidades pesqueras enfrentan importantes restricciones en el acceso a los mercados financieros y (v) aunque los hogares pescadores obtienen más ingresos que los que no lo son, exhiben una educación y alfabetización más bajas. Estos resultados muestran que la PPE es un amortiguador contra la vulnerabilidad de las comunidades pesqueras. Es posible que se necesiten estrategias de conservación estrictas para sostener la pesca artesanal, pero ellas deben ir acompañadas de fuentes alternativas de ingresos, como esquemas de compensación, protección social o políticas que permitan medios de vida alternativos. JEL Codes: D13, I21, J22, J46, Q22, Q56.

Palabras clave: Enfoque de medios de vida sostenibles (SLA), pesquerías de pequeña escala, activos, pobreza, brecha educativa, seguridad alimentaria, Colombia.

\section{INTRODUCTION}

Fishing is a key component in the livelihoods of millions of people (Asiedu 2011). Approximately $90 \%$ of the almost 40 million people that the Food and Agricultural Organization (FAO) register globally as fishers are classified as smallscale, and $97 \%$ of them are located in developing countries (FAO 2021).

However, there is limited information about the livelihoods of small-scale fishing (SSF) communities in developing countries (Bailey and Jentoft 1990; Cinner et al. 2010). Collecting reliable data is difficult (Pita et al. 2019) and the sector lacks quantitative studies on socioeconomic variables (FAO and World Fish Center 2008). Research on fisheries has emphasized biological issues (Béné 2003). By contrast, there is little rigorous data estimating the poverty level of fishing households (Willmann 2004). In some cases, fishers' poverty has been inferred rather than proven (Thorpe et al. 2007). A review of 202 articles concluded that fisheries' role in poverty alleviation is unclear because good conceptual models are lacking (Béné et al. 2016). Moreover, the estimation of poverty indexes and the measurement of vulnerability depend on reliable longitudinal data (Béné 2009), which has not been available. In a special issue of Marine Policy (Vol. 101, March 2019), coordinated by Pita et al. (2019), authors not only discuss the challenges of managing small-scale fisheries under scenarios of poor data, but present a variety of innovative approaches for SSF data collection, including participatory methods.

Despite this lack of detailed information, there exist multiple proposals and interventions to improve the well-being of these communities and the sustainability of fishing resources. These solutions have centered on increasing the efficiency of SSF while implementing mechanisms to conserve fish stocks, through a combination of management strategies to limit access (e.g. protected areas, community and territorial use rights, community-based management, closed seasons) and incentives to reduce fishing effort (e.g. alternative livelihoods, subsidies, conservation agreements) (Allison and Ellis 2001; Cinner 2014). As Cinner et al. (2009) argue, successful interventions to reduce fishing efforts in overexploited fisheries require understanding the socioeconomic context in which fishers operate.

Research on livelihoods in SSF communities has increased recently, and shows heterogeneous results in developing countries. For instance, in terms of income levels, findings are ambiguous: while some authors find that fishing communities are poorer than the national level, as in Malaysia (Teh and Sumaila 2007), or more vulnerable than other groups, as in Ghana (Asiedu 2011), other authors show that fishers are not always the poorest of the poor and can even be better off than non-fishing households, as shown in Malawi, Uganda and Kenya (Allison 2005), or Philippines, Bangladesh, India, Senegal and Tanzania (Tietze et al. 2000).

Besides, as Thorpe et al. (2007) assert, poverty cannot be captured only in monetary terms: liter- 
acy, access to education, health, and clean water, as well as other factors are dimensions of wellbeing. Landownership, debt, financial capital, and marginalization from political decision-making affect income and well-being in SSFs (Béné and Friend 2011; Nayak et al. 2014). Others have highlighted the importance of SSF interventions to strengthen tenure and community governance, cover upfront opportunity costs, reduce vulnerability to market shocks by supporting a broader livelihood portfolio, and relax credit constraints (Barr et al. 2019).

In the framework of socio-ecological systems, some researchers have proposed indexes of vulnerability (Béné 2009) or adaptive capacity (McClanahan et al. 2008, 2009; Cinner et al. 2012; Moreno-Sánchez and Maldonado 2013; Maldonado and Moreno-Sánchez 2014) for SSF communities. These indexes have included income, occupational diversification, poverty, material assets, wealth, dependence on natural resources, and social capital.

Income diversification is a livelihood strategy for fishing households (Ellis and Allison 2004; Thorpe et al. 2007; Béné 2009). Fishing is generally a part-time activity that is complemented with other sources of income. But fishing is also an essential component of food security, not only for fishing households but for their communities. SSF goes beyond being a last-resort activity for the poorest of the poor; it is relevant to other socioeconomic groups (Garaway 2005). For example, Kawarazuka (2010) analyzes the role of SSFs in the food and nutrition security of poor rural households in developing countries, particularly in Africa, Asia, and Oceania. The author shows that fish captured in common-pool resources are used for self-consumption and traded in local markets and highlights how those fisheries can compensate for the shortage of food in poor households. He also finds that SSFs provide other income-generation opportunities such as processing and trading and that -among those better-off- fishing income is used to purchase non-staple foods and to invest in agriculture. Kawarazuka (2010) also describes the importance of fish in rural poor communities for the consumption of high-quality nutrients. Confirming these findings, Kawarazuka and Béné (2010) identify two pathways between small-scale fisheries and household nutritional security: (i) the direct nutritional contribution from fish consumption; and (ii) the increased purchasing power through the sale of fish. While some members of SSF households fish as their primary source of income, and some households engage in economic activities not related to fishing at all, fishing shapes the livelihoods and food security of all households in these communities.

In general, these studies confirm the heterogeneity within and among fishing communities and the relevance of social, economic, and institutional context in understand poverty levels and vulnerability of fishing households. In the same way, the literature discussed above confirms the role of fishing in the food security of fishing households and their communities.

In Latin America, however, socioeconomic studies of SSF are limited and Colombia is not the exception. According to the Organisation for Economic Co-operation and Development (OECD 2016), there are no reliable statistics about Colombia's SSF activities and communities. For the case of Colombia, there are only some cross-sectional surveys, characterizing some aspects of fishing households (García 2010; Agudelo et al. 2011; Moreno-Sánchez and Maldonado 2013; Viloria et al. 2014). These studies have found that fishers are typically adults who belong to households exhibiting low education levels and assets ownership, whose livelihoods depend on more than one source of income. Others have collected information about fishing gear, types of boats, captured species, and levels of effort (Rueda et al. 2011; Viloria et al. 2014). However, little is known about the dynamics of the fishing household economy. Notably, there is scarce literature on the variability of income throughout the year. 
Our objective then is to describe the demographics, assets, livelihood strategies, food security, poverty level, and sustainability of a fishing village in the Colombian Caribbean (Barú-Cartagena). We hypothesize that fishing and non-fishing households differ with respect to characteristics such as education, access to financial capital, income level and diversification, and food security. We collected information from fishing and non-fishing households in the village of Barú, administering monthly socioeconomic surveys from July 2018 to September 2019. The data collection started with a baseline and was followed by monthly surveys administered to each participating household. The sample included around 100 fishing households and 150 non-fishing households. To analyze the data, we organized the information following the Sustainable Livelihoods Approach (SLA).

Our contribution is a comprehensive description and analysis of a fishing community's livelihood that involves: (i) the characterization of fishing and non-fishing households in terms of capital (human, financial and social), livelihood strategies (diversification of sources of income, access, use of financial services, and the role of social capital), and livelihood outcomes (monetary poverty and food security); and (ii) a longitudinal study that collects monthly panel-data information at a household level for a year.

\section{MATERIALS AND METHODS}

\section{Conceptual framework}

We follow the conceptual framework of the sustainable livelihood approach (Chambers and Conway 1992; DFID 1999). The SLA assumes that household well-being depends on consumption and production decisions (including livelihood strategies) in light of its endowment of assets (human, social, natural, physical, and financial) in a specific institutional and geographical framework, and the interactions of these factors (Allison and Ellis 2001). Assets we consider are as follows: (1) human capital: education and employment; (2) social capital: participation in organizations and supporting networks; (3) physical capital: housing, appliances, vehicles, livestock, and fishing assets; and (4) financial capital: savings, credit. The livelihood strategies considered are labor and non-labor strategies, fishing, use of financial services, allocation of expenditures for household consumption, and food security strategies. Finally, outcomes include household income, expenditures, food security, poverty, and inequality.

\section{Study site}

Barú peninsula is part of the rural area of the Tourist and Cultural District of Cartagena de Indias in the department of Bolívar, Colombia. It covers approximately 7,117 hectares and consists of three villages: Ararca, Santa Ana, and Barú. This research project was implemented in Barú village (Figure 1). The number of residents in Barú village averages 2,700-2,800 inhabitants in the populated center, mostly ancestral Afrodescendants (Lizarazo and López 2007; Márquez 2014; Mendoza and Moreno-Sánchez 2014).

Barú is a major tourist destination with high demands of ecosystem services such as seafood and recreation. It is located in the area of influence of the National Natural Park Corales del Rosario and San Bernardo (MADS 2012), where commercial fishing is prohibited. However, subsistence fishing is allowed. In the most recent management plan, the park authorities recognized small-scale fishery activities as traditional and ancestral practices (PNN 2020). In practice, longline and diving are the most frequent fishing arts. The management plan also identifies some species that currently are being harvested and are under some level of threat. There are two zones within the park clearly defined and managed as 


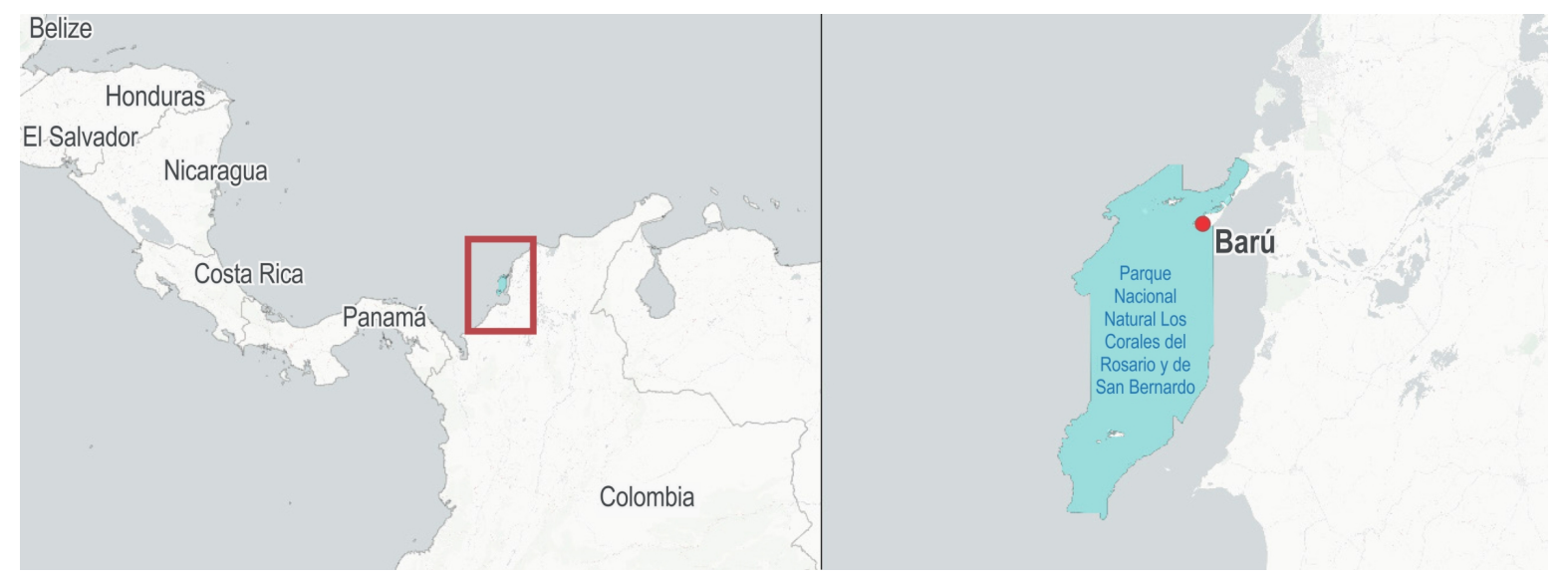

Figure 1. Location of Barú Peninsula adjacent to the marine protected area Corales del Rosario and San Bernardo National Park (https://runap.parquesnacionales.gov.co/).

no-take zones, whose characteristics imply that this fishery runs under a semi-open access regime. At the time of the survey, there was no official record of fishers.

In terms of infrastructure, Barú village lacks an adequate aqueduct and sewer service, and rainwater is the primary source of water supply for most households. Drinking water comes from Cartagena by boats adapted to transport water -known as bongoductos (Pineda et al. 2006; Rodríguez-Sánchez et al. 2016). There is a health post in the village which offers first aid, primary care, and vaccination campaigns (MADS 2012; Villamil et al. 2015); a health center is currently under construction and is expected to provide more services and better equipment.

\section{Target and sample population}

In July of 2018, the population of Barú village accounted for 801 households: 158 fishing households (F-hh) and 643 non-fishing households (non-F-hh). We randomly selected a stratified sample of 255 households (97 F-hh, and 158 nonF-hh) to carry out the surveys. The size of the sample included oversampling of $10 \%$ to cope with attrition during the information gathering process. The sample anticipates a margin of error of $5 \%$ and a confidence level of $95 \%$. The baseline survey was conducted between July and October 2018; follow-up surveys were administered monthly from October 2018 to October 2019.

\section{Collection instruments}

We ran a baseline survey to (i) register the participating households; (ii) gather general information assumed to remain constant throughout the study period; and (iii) initiate the collection of socioeconomic information. The baseline survey consisted of seven sections: (i) household characteristics and economic activities; (ii) household expenditures; (iii) household assets and income; (iv) finances; (v) fishing; (vi) food security; and (vii) land tenure.

Follow-up surveys were conducted once a month for each household for the following consecutive 11 months and had the same structure as the baseline except for the sections on household characteristics and land tenure. During the follow-up survey, new household members were recorded, as well as those who left.

Two members of the Barú community were trained to apply the survey and became interviewers and co-researchers for the project. This made it easier for the community to accept the 
researchers and thus be collaborative in offering information. The interviewers were trained in topics related to ethics, survey administration, and the objectives of the project.

\section{Variables}

In order to capture the different dimensions of the SLA, we use information to construct statistics related with several variables (Table 1).

For most of these indicators, reported statistics compare average values for fishing and non-fishing households. In some other cases, particular indicators are proposed.

For income diversification, we use the Simpson Diversity Index (SDI; Etea et al. 2019). According to this approach, if a household has only one activity the index will be zero. To the extent that the household participates in more activities and the income it receives from these activities is similar, the index tends to one. Therefore, the greater the diversification of activities and the distribution of income deriving from them, the greater the SDI.
The indicator for food security was calculated using an adaptation of the Latin American and Caribbean Food Security Scale (ELCSA) (FAO 2012). Insecurity levels were estimated using the answers to the following questions, with reference to the week previous to the survey:

- Did you want to vary the household nutrition and could not?

- Did you have to reduce the food portion of a household member?

- Did someone in this household go to bed hungry?

- Did someone in this household have to skip breakfast, lunch, or dinner due to lack of food?

If the answer to all four questions is yes, the household is considered in severe insecurity. If the answer is yes to two or three questions, the household is in moderate insecurity, and if the answer is yes to one of the questions the household is in slight insecurity. Finally, if the answer to all questions is no, the household is considered to have food security.

Table 1. Summary of variables to be evaluated in the SLA approach.

\begin{tabular}{lll}
\hline Dimension & \multicolumn{1}{c}{ Variable } & \multicolumn{1}{c}{ Indicator } \\
\hline \multirow{2}{*}{ Endowments } & Human capital & Household size, age and sex distribution, literacy and schooling \\
& Social capital & Organizations, fish sharing \\
& Physical capital & Housing, household appliances, vehicles, livestock, fishing assets \\
& Financial capital & Savings, credit \\
Strategies & Labor & Labor force participation, Labor activities, Income diversification \\
& Fishing & Profile of fishers, catches, fishing techniques, species \\
& Non-labor & Remittances, transfers \\
& Use of financial capital & Savings and credit, consumption, food and protein consumption \\
& Food security & Shortage responses \\
& Income and expenditures & Income, expenditures, income sources \\
Outcomes & Food security & Scale of food security \\
& Poverty & Headcount poverty index \\
& Inequality & Gini coefficient \\
& Sustainability & Fishing sustainability \\
\end{tabular}


To measure the inequality of income distribution and household expenditure in the Barú village, we estimated the Gini coefficient for labor income, non-labor income, total income, household per capita income, and total expenditure.

To approach the potential effects of fishing on the ecological system, we analyzed the degree to which fishing gear affects the ecosystem, and the conservation status of the main species caught.

To do this, the approach proposed by Bjordal (2005) was used, which considers seven categories of effects on coastal marine ecosystems: size selection, species selection, incidental mortality, ghost fishing, habitat effects, energy efficiency and catch quality. A score of favorability (unfavorable $=1$ to favorable $=10$ ) of the gear with respect to the ecosystem is assigned to each of these categories, which are then averaged arithmetically, resulting in an overall index of the average effect of each gear on the ecosystem. Weighted scores were calculated for the average use of each gear type, measured as the percentage of fishers who used each gear type in each month during the survey period.

\section{RESULTS}

\section{Household's endowments}

\section{Human capital}

Households in Barú were composed of four persons on average. Barú had a predominantly young community, with about $71 \%$ of the population aged under 40; the median age was 26 years. Although the gender distribution was even (52.7\% men and $48.3 \%$ women), $24.8 \%$ of nonF-hh were headed by women, while among F-hh this percentage was only $4.9 \%$.

Households showed important differences in literacy rate and schooling. The percentage of people (15 years and older) who can read and write was higher for non-F-hh than for fishing ones (Table 2). This difference was greater when heads of household were considered: $95 \%$ of household heads in non-F-hh can read and write, whereas $78 \%$ of those in F-hh can do so. Both differences were statistically significant.

Educational achievement by household members older than 24 years in non-F-hh was significantly higher than that of F-hh (7.7 versus 6.1 years). When considering only the heads of household, the difference in education level was accentuated. Non-F-hh heads were more educated (6.3 years) than those from F-hh (4.7 years).

Twenty-seven percent of the population over 18 years of age completed secondary education (34\% in non-F-hh and $18 \%$ in F-hh). In both types of households, the percentage of women who have completed secondary education was higher than that of men (Table 2). Regarding school attendance rate among 5 to 18 year old household members, there were no significant differences: $75 \%$ and $80 \%$ for non-fishing and fishing households, respectively.

Finally, 53\% of individuals aged between 18 and 28 were considered NEET (Not in Education, Employment or Training). For women, this rate rose up to $72 \%$; i.e. 7 out of 10 women in this age range were neither working nor studying. We believe this was related to childbearing and childrearing by women in this age group, as well as limited job opportunities for both men and women. For men, this rate was $28 \%$. When comparing types of households, the NEET rate was higher for non-F-hh than for F-hh, although this difference was not significant. The estimated rate for Barú was double that reported at the national level.

\section{Social capital}

The participation of Barú's households in community fisheries organizations is part of their structural social capital. The village had four formally constituted fishing organizations. The organizations' main objectives were to stabilize their members' income and to promote marketing 
Table 2. Summary of human capital indicators in Barú (baseline survey). F-hh: fishing households, non-F-hh: non-fishing households.

\begin{tabular}{|c|c|c|c|c|}
\hline & & F-hh & Non-F-hh & Colombia \\
\hline Dependency ratio ${ }^{\mathrm{a}}$ & & 0.52 & 0.51 & $0.64^{\mathrm{b}}$ \\
\hline \multirow[t]{2}{*}{ Literacy rate $(>14$ years old $)$} & Total & $85.9 \% * *$ & $92.8 \%$ & $95 \%{ }^{b}$ \\
\hline & Household head & $77.5 \% * *$ & $94.8 \%$ & \\
\hline \multirow{4}{*}{$\begin{array}{l}\text { Schooling (years of attending, } \\
\text { older than } 24 \text { years) }\end{array}$} & Women & $6.2 *$ & 7.1 & 8.4 \\
\hline & Men & $4.6 * *$ & 6.7 & 8.6 \\
\hline & Total & $5.4^{* *}$ & 6.9 & $8.5^{\mathrm{c}}$ \\
\hline & Household head & $4.7^{* *}$ & 6.3 & \\
\hline \multirow{4}{*}{$\begin{array}{l}\text { Complete high school education } \\
\text { (>18 years old })\end{array}$} & Women & $26 \% *$ & $38 \%$ & $21.9 \%$ \\
\hline & Men & $11 \% * *$ & $29 \%$ & $22.2 \%$ \\
\hline & Total & $18 \% * *$ & $34 \%$ & $22.1 \%^{\mathrm{c}}$ \\
\hline & Household head & $7.1 \% * *$ & $19.6 \%$ & \\
\hline \multirow[t]{3}{*}{ \% NEET (18-28 years) } & Women & 72.3 & 71.43 & 37 \\
\hline & Men & 28.3 & 36.8 & 14.8 \\
\hline & Total & 49 & 55.9 & 26.1 \\
\hline
\end{tabular}

aThe age dependency ratio is: 'the ratio of dependents people younger than 15 or older than 64 to the working-age population (those ages 15-64)' (https://data.worldbank.org/indicator/SP.POP.DPND).

bWorld Bank (2020).

'Barro and Lee (2013).

$* \mathrm{p}<0.05, * * \mathrm{p}<0.01$

and fishing control practices. According to the baseline survey, $5 \%$ of non-F-hh and $39 \%$ of F-hh were linked to one of these organizations.

Structural capital also included receiving fish as a gift and receiving support when a household needs a loan or was experiencing food shortages; these examples show the existence of support networks. In the baseline survey, $35 \%$ of non-F-hh and $27 \%$ of $\mathrm{F}$-hh reported having received fish as a gift; these percentages were significantly lower during the follow-up survey, averaging $24 \%$ and 19\%, respectively (Figure 2).

It should be noted that the practice of gifting fish can also be related to cognitive capital, as it expresses values of solidarity. On average, about $28 \%$ of F-hh reported giving away part of their catch to other households (Figure 2). Note that, in the month of September, both at the baseline and in the follow-up survey, the percentage of F-hh that gifted fish to others was as high as nearly $50 \%$.

In terms of sources of support in case of food shortage, $22 \%$ and $12 \%$ of non-fishing and F-hh, respectively, turned to their families; $5.4 \%$ of non-F-hh and $2.4 \%$ of F-hh went to their friends. These differences are not statistically significant.

\section{Physical capital}

Five categories of physical assets were examined in Barú households: housing and other real estate (farms and lots), household appliances, vehicles, livestock, and fishing assets (Figure 3). Households in Barú exhibited a high level of ownership of housing and household appliances. For instance, the percentage of households that own their residence was $70 \%$ and $81 \%$ for nonfishing and fishing households, respectively. 


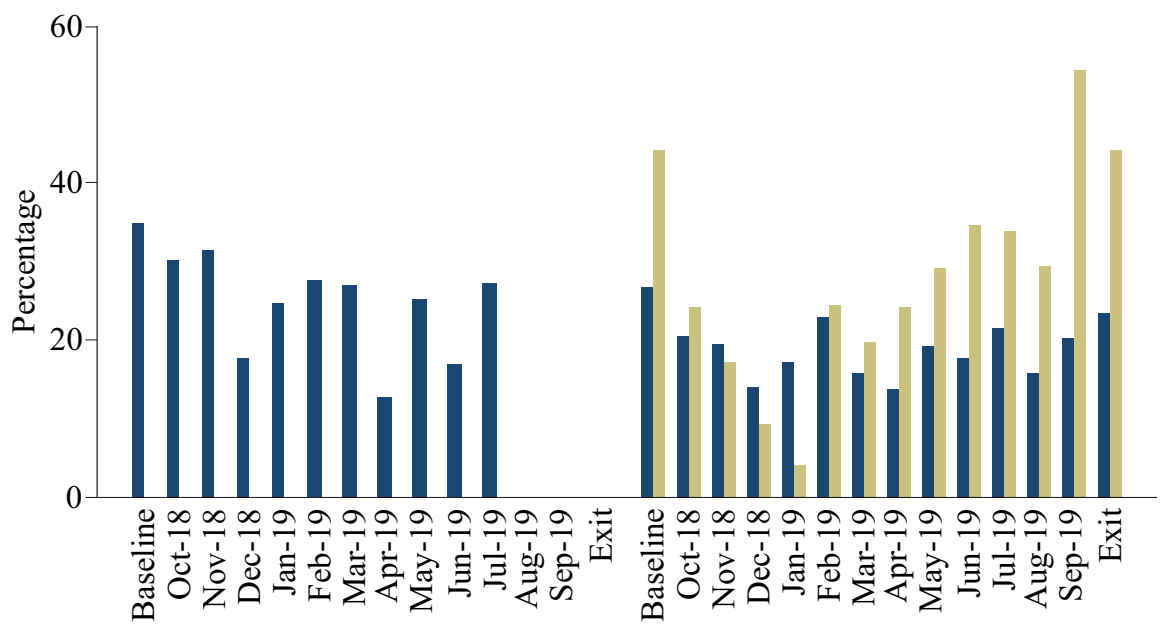

Non-fishing households

Fishing households

$\square$ Receive Give

Figure 2. Proportion of households who received and gave fish as a gift.

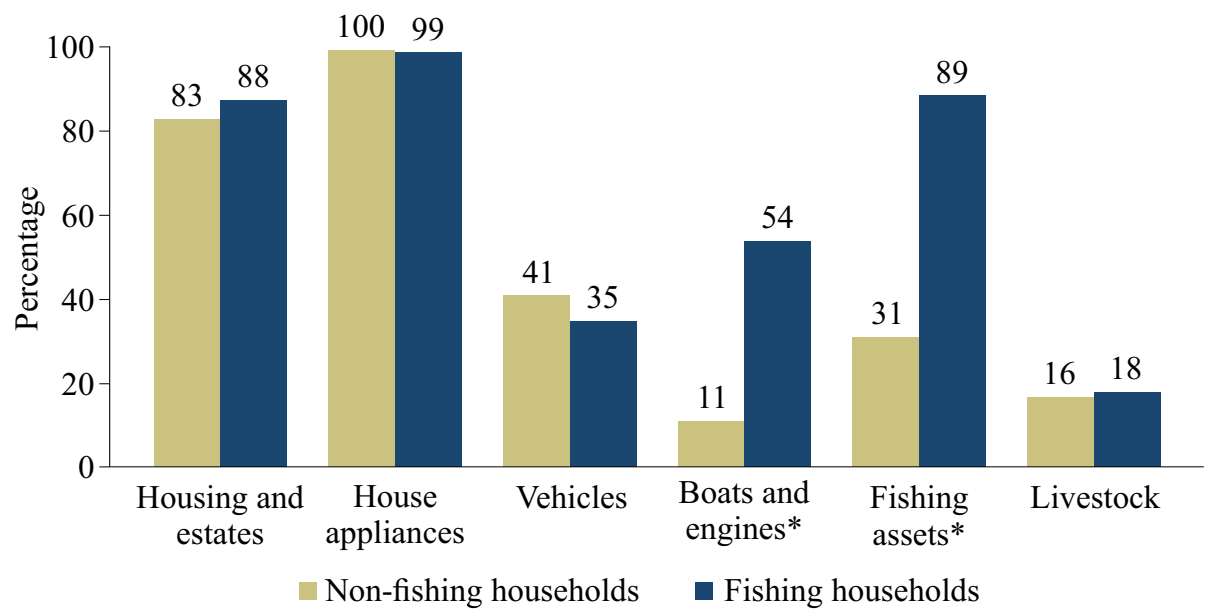

Figure 3. Percentage of non-fishing and fishing households which own physical assets $\left({ }^{*} p<0.01\right)$.

However, the ownership of other properties such as lots and parcels was low; only 19\% report owning lots and $1 \%$ rural parcels. No differences were found in terms of vehicle ownership (mainly motorbikes) or livestock. As expected, F-hh report greater ownership of boats, boat engines and productive assets for fishing, such as nets, handlines, fish traps, and coolers.

Among fishing assets, handlines and free-diving equipment were the most common gear among F-hh. Likewise, of these households, 43\% owned boats or canoes, $35 \%$ boat engines, and $36 \%$ refrigerators or coolers. Almost a quarter of non-F-hh had freezers, and around 10\% owned fishing gear such as handlines and trolling equipment. On average, the total value of assets was almost the same for both types of households (Table 3). However, when classified in categories, there were some differences mainly related to the value of fishing assets that, as expected, 
Table 3. Estimated value of physical assets owned by fishing and non-fishing households (in US dollars and proportions) adjusted by the purchasing power parity of 2018 (US\$-PPP).

\begin{tabular}{lcccccc}
\hline & \multicolumn{2}{c}{ Non-fishing households } & & \multicolumn{2}{c}{ Fishing households } & \\
\cline { 2 - 3 } Variable & Observed & Mean (SD) & & Observed & Mean (SD) & Difference \\
\hline Housing and real estate & 158 & $49,142(95,759)$ & & 97 & $48,288(80,353)$ & 854 \\
Appliances and electronics & 158 & $1,462(3,083)$ & & 97 & $1,410(1,786)$ & 53 \\
Vehicles & 158 & $365(991)$ & & 97 & $248(476)$ & 117 \\
Boats and boat engines & 158 & $1,162(5,442)$ & & 97 & $1,607(3,349)$ & -445 \\
Fishing assets & 158 & $150(610)$ & & 97 & $756(1,358)$ & $-603^{*}$ \\
Livestock & 158 & $131(869)$ & & 97 & $107(540)$ & 23 \\
Total physical assets & 158 & $52,412(96,228)$ & & 97 & $52,412(81,952)$ & 0 \\
Proportion of households & 158 & $0.31(0.46)$ & & 97 & $0.89(0.32)$ & $-0.58^{*}$ \\
$\quad$ with fishing assets & & & & & & \\
Proportion of households & 158 & $0.11(0.31)$ & & 97 & $0.54(0.50)$ & $-0.43^{*}$ \\
with boats or boat engines & & & & & & \\
\hline
\end{tabular}

$* \mathrm{p}<0.01$

was higher for F-hh. There were other differences in the value of boats and of housing, but they were not statistically significant.

The distribution of the value of assets by quintiles shows that assets are relatively evenly distributed across the population. However, in F-hh, inequality is a little more marked, as the first two quintiles of this group account for only $27 \%$ of the value of assets. Ownership of fishing-related assets is distributed evenly among the quintiles, although this is not the case for boats and engines, which are more statistically frequent among households in the 4th and 5th quintiles.

\section{Financial capital}

During the period of analysis, 93\% of F-hh on average reported having informal savings, while this proportion was only $28 \%$ for non-F-hh. NonF-hh save informally, mostly through piggy banks $(29 \%)$, building materials $(17 \%)$ and animals $(21 \%)$. F-hh do so mainly through piggy banks (34\%), animals (22\%) and cash (15\%).

In the baseline survey and throughout the fol- low-up surveys, on average, 10\% of households reported having formal savings, from which $81 \%$ of the non-fishing and $60 \%$ of F-hh reported depositing these savings in banks. The main reasons for not saving formally were lack of money (69\%), unwillingness (14\%), high transaction costs or low returns $(5 \%)$, not knowing how to access formal services (4\%), not trusting financial institutions (3\%), financial offices are too far away $(2 \%)$, or having other types of savings $(0.4 \%)$.

During the period of analysis, on average, 24\% of non-F-hh and $26 \%$ of F-hh received informal loans. Loan sharking -known in Colombia as gota a gota or pagadiario - was the most representative source of informal loans for both types of households (39.5 for non-F-hh and $43.8 \%$ for F-hh). Food and supplies bought on credit $(21.5 \%$ and $22.9 \%$ ) and loans from lenders other than usury $(16.3 \%$ and $12.4 \%)$ were also noteworthy. Traditionally, access to formal credit has been scarce in this community. During the period of analysis, only $0.5 \%$ of non-F-hh and $1.9 \%$ of F-hh requested loans from the formal sector. 
The level of total indebtedness averaged US\$ 613 US\$-PPP (US dollars and proportions) for non-F-hh and US\$ 523 US\$-PPP for F-hh, the difference being statistically significant. F-hh presented a lower level of indebtedness, a higher level of savings, and greater receipt of formal loans.

\section{Livelihood strategies}

\section{Labor strategies}

On average, the economically active population was 40 years old with 6.8 years of education. Labor force participation, estimated as the number of people aged 15 and older who were working out of the total population in this age range, reached $52.4 \%$ in Barú, which was lower than the national figure for the same year $(68.4 \%)$ (World Bank 2020). However, employment in the village was seasonal and can therefore fluctuate over time. In non-F-hh, labor force participation was $49.5 \%$, while in F-hh it was significantly higher at $56.3 \%$. In other words, F-hh tended to have more people working than did non-F-hh: an average of
1.75 economically active people per household versus 1.37, respectively. F-hh had higher labor participation in the younger strata (15-19 years) and in the older population (60-79 years and above). More than half (56\%) of adults over 60 in F-hh continued to provide income to the household, while only a third of this population participated in some economic activity in non-F-hh.

There were more men than women working in both types of households: of the total number of people who were working, $34.4 \%$ were women. The labor participation of women in non-F-hh was higher than in F-hh: $38.2 \%$ versus $33.6 \%$. Labor participation of the head of households in both groups reaches $51 \%$.

The ratio between the theoretically inactive or dependent population (under 15 years and over 65 years) and the labor force (15-65 years) in Barú was $52 \%$ in non-F-hh and $51 \%$ in F-hh. In other words, for every two persons of potential working age, there was one economically dependent person in both F-hh and non-F-hh. Between 4 and 14 $\%$ of people older than 15 reported having a second economic activity (Figure 4).

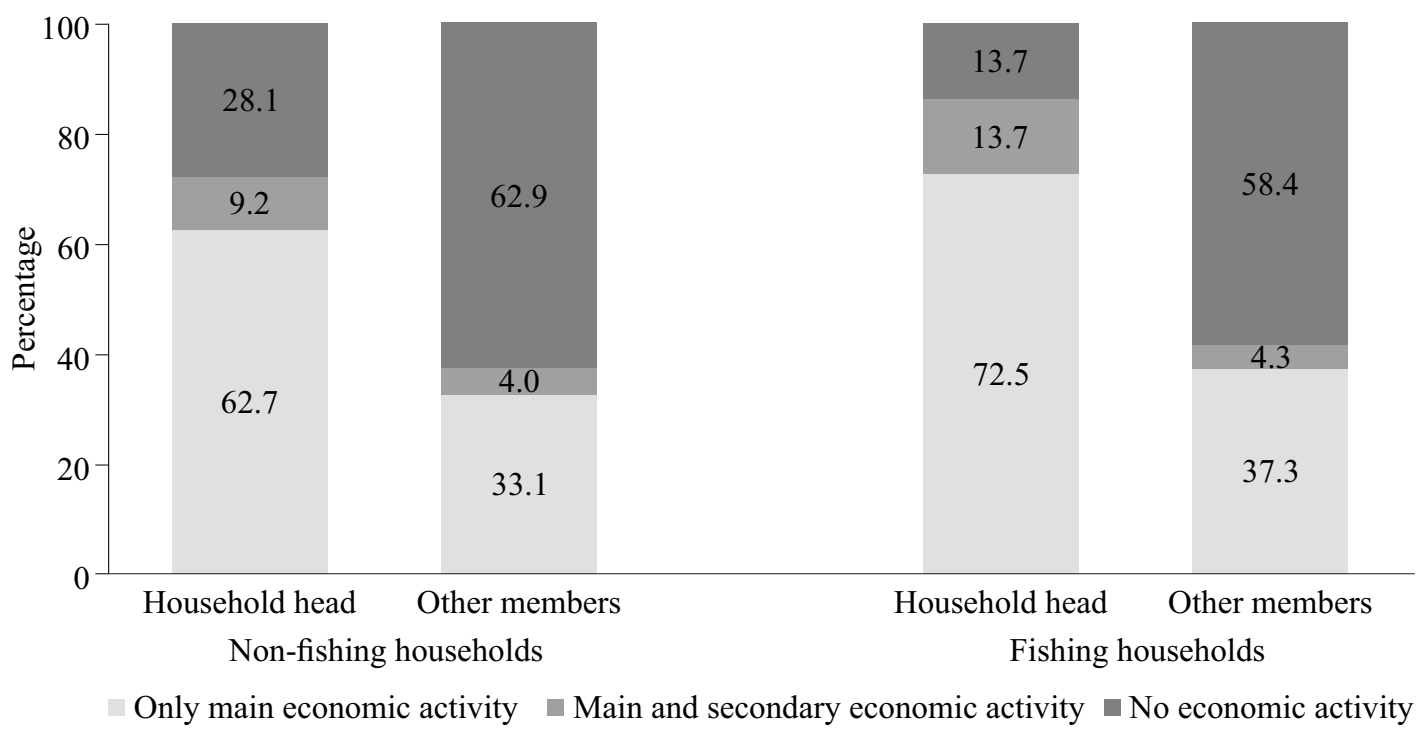

Figure 4. Percentage of household heads and other members (15 years old and older) working in zero, one, or two economic activities (for all survey months). Note: $8 \%$ of this population is studying, of whom $90 \%$ only study, while the remaining percentage works and studies at the same time. 
Workers who reported carrying out only one economic activity allocate between 40 (F-hh) and 47 (non-F-hh) hours per week to that activity. When workers carry out two income-generating activities, they spent up to 52 hours per week, but reduced the average hours engaged in the primary activity. The share of F-hh which has an activity was significantly higher when compared to that in non-F-hh (Figure 5). Having a second occupation seemed to be related to the tourism seasons in the case of F-hh.

Main activities among heads of non-F-hh were tourism, the production and sale of handicrafts, construction, and sale of food. For heads of F-hh, these activities included fishing, transport, watch keeping (security) and fishing-related activities (consisting mainly of trading fish and rental of fishing equipment). Most frequent secondary economic activities for the heads of non-F-hh were food sale and handicrafts, while for F-hh were fishing, construction and food sales.

When analyzing working members other than the household head, for both types of households, most important sectors were food sales and tourism, with tourism being the most important in non-F-hh and food sales predominating in F-hh.
In addition, in F-hh, about $8 \%$ of non-head, working household members were engaged in fishing as their main activity. In terms of secondary activities, the predominant economic sector in both types of households was food sales, followed by mixed and other activities for non-F-hh and F-hh and construction for F-hh.

Participation in the formal labor market, under contract and with social benefits, included only $1.5 \%$ of workers, with no significant differences between non-fishing and F-hh. This implies that $98.5 \%$ of the workers in Barú were in the informal sector. People with formal jobs reported significantly higher incomes than those with informal jobs: US\$ 862 versus US\$ 631 US\$-PPP per month per worker. Relative to income diversification, we found that households carry out on average 1.4 different activities from which they derive income, and F-hh diversify significantly more than non-F-hh: 1.71 versus 1.16 economic activities. About $72 \%$ of non-F-hh had one activity at most, while about $58 \%$ of F-hh had two or more activities (Figure 6).

The proportion of labor income derived from the primary economic activity for all households and for households with more than one economic

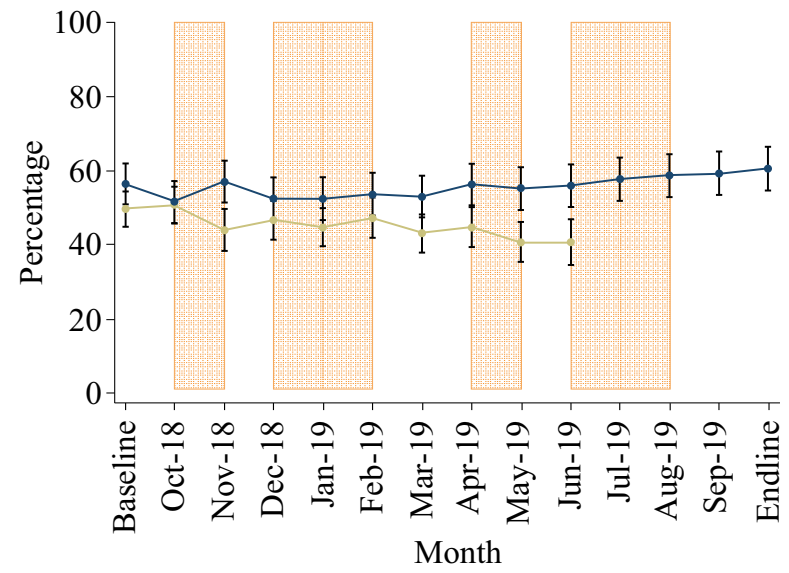

$\longrightarrow$ Non-fishing households
CI 95\%

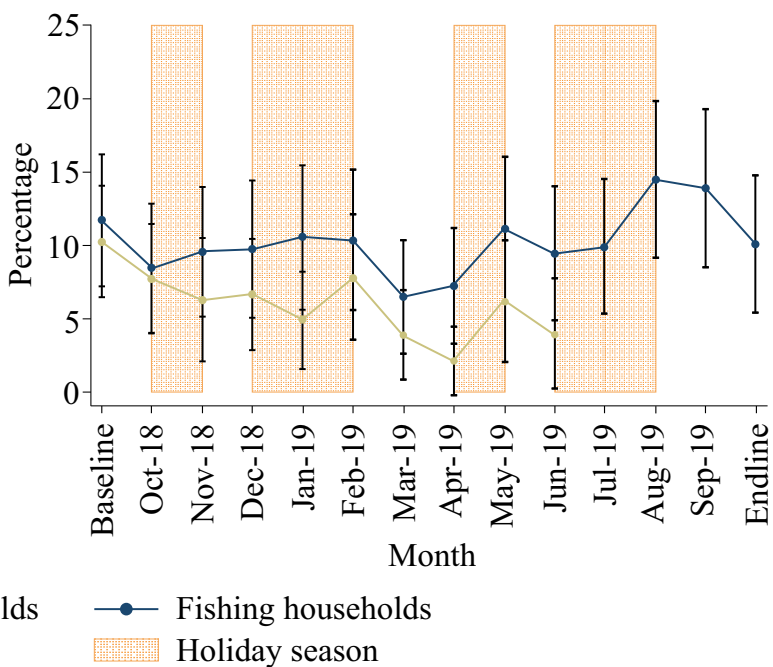

Figure 5. Percentage of the population (15 years and older) with primary economic activity (left) and secondary economic activity (right). 

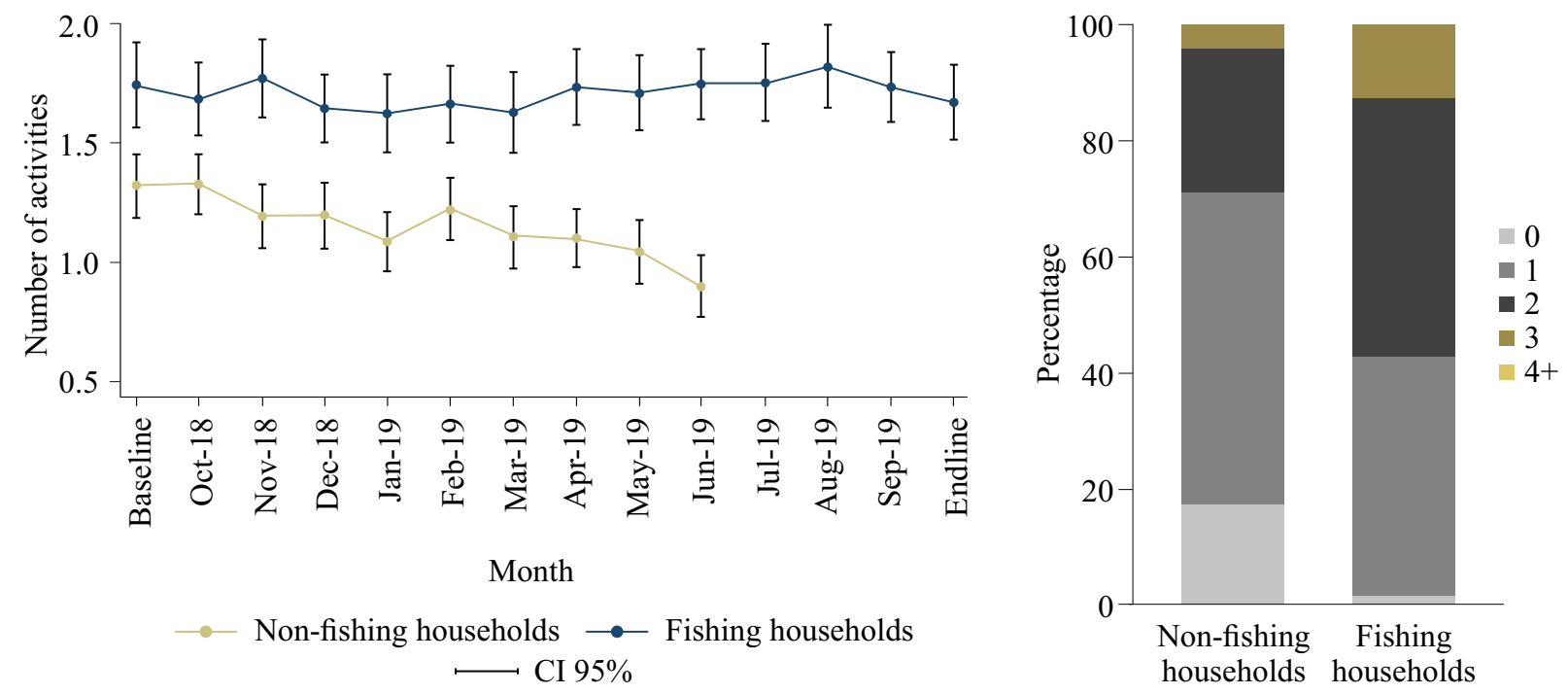

Figure 6. Number of economic activities by type of household during the study period (left), and distribution of households by number of economic activities (right)

activity was higher for non-F-hh who, on average, derived $90 \%$ of their labor income from the main activity, while F-hh derived $78 \%$ of their labor income from this activity (Table 4). According to the Simpson Diversity Index, F-hh diversified their income significantly more than non-Fhh. Households did not exhibit large diversity of income in the main economic activity; however, secondary economic activity tended to be more diverse within households.

\section{Fishing activity}

One hundred percent of the respondents who fish were men, with an average age of 45.6 years and an average of 4.28 years of education. Of the heads of F-hh, 58.3\% were engaged in fishing. Fishing was the primary economic activity for $31 \%$ of the people working in F-hh, while $4 \%$ engaged in it as a secondary activity.

Fishing households allocated their catch to three uses: sale (85\%), self-consumption (13\%), or giving it as a gift to other households (2\%). The latter two categories were part of the households' non-monetary income derived from fishing activity.
For the households surveyed, the total catch of fish resources averaged $9,000 \mathrm{~kg}$ of fish per month. February and July 2019 were the months with the highest catch, and January and June the lowest -the latter coinciding with important holiday seasons. This catch was around $97 \mathrm{~kg}$ per month per household, which was equivalent to around $23 \mathrm{~kg}$ per week. The monthly catch per fisherman was around $88 \mathrm{~kg}$, while the catch per day averaged $4.8 \mathrm{~kg}$.

When fishing was the main activity, most popular techniques were handlining (44\%) and diving (38\%). When fishing was considered a secondary activity, diving was the preferred fishing technique ( $76 \%$ versus $13 \%$ of handlining). During the period of study, we did not find variation in the use of fishing gear. On average, only $4 \%$ of F-hh diversified their gear for the whole period of the survey, combining handlining with diving, nets, pots, throw nets or longlines. Handlining was the gear with the highest catch per unit of effort (CPUE) during most of the period under study $\left(131 \mathrm{~kg}\right.$ fisherman ${ }^{-1}$ month $\left.^{-1}\right)$, while fish traps were the lowest $\left(32 \mathrm{~kg}\right.$ fisherman ${ }^{-1}$ month $^{-1}$ ) (Figure 7). 
Table 4. Labor income diversity measures by type of household.

\begin{tabular}{llcc}
\hline Variables & $\begin{array}{c}\text { Non-fishing } \\
\text { Mean (SD) }\end{array}$ & $\begin{array}{c}\text { Fishing } \\
\text { Mean (SD) }\end{array}$ & Means difference \\
\hline Number of economic activities & $1.160(0.021)$ & $1.709(0.022)$ & $-0.549^{*}$ \\
Proportion of income from the main activity & $0.899(0.005)$ & $0.783(0.006)$ & $0.115^{*}$ \\
Proportion of income from the main activity & $0.714(0.009)$ & $0.627(0.005)$ & $0.088^{*}$ \\
$\quad$ when household has more than one activity & $0.131(0.007)$ & $0.267(0.007)$ & $-0.136^{*}$ \\
$\quad \begin{array}{l}\text { Simpson Diversity Index } \\
\text { (for the main activity of household members) }\end{array}$ & $0.370(0.009)$ & $0.459(0.005)$ & $-0.089^{*}$ \\
$\quad$ Simpson Diversity Index & & & \\
$\quad$ for household members with more than one & & & \\
$\quad$ economic activity) & & & \\
\hline
\end{tabular}

${ }^{*} \mathrm{p}<0.01$
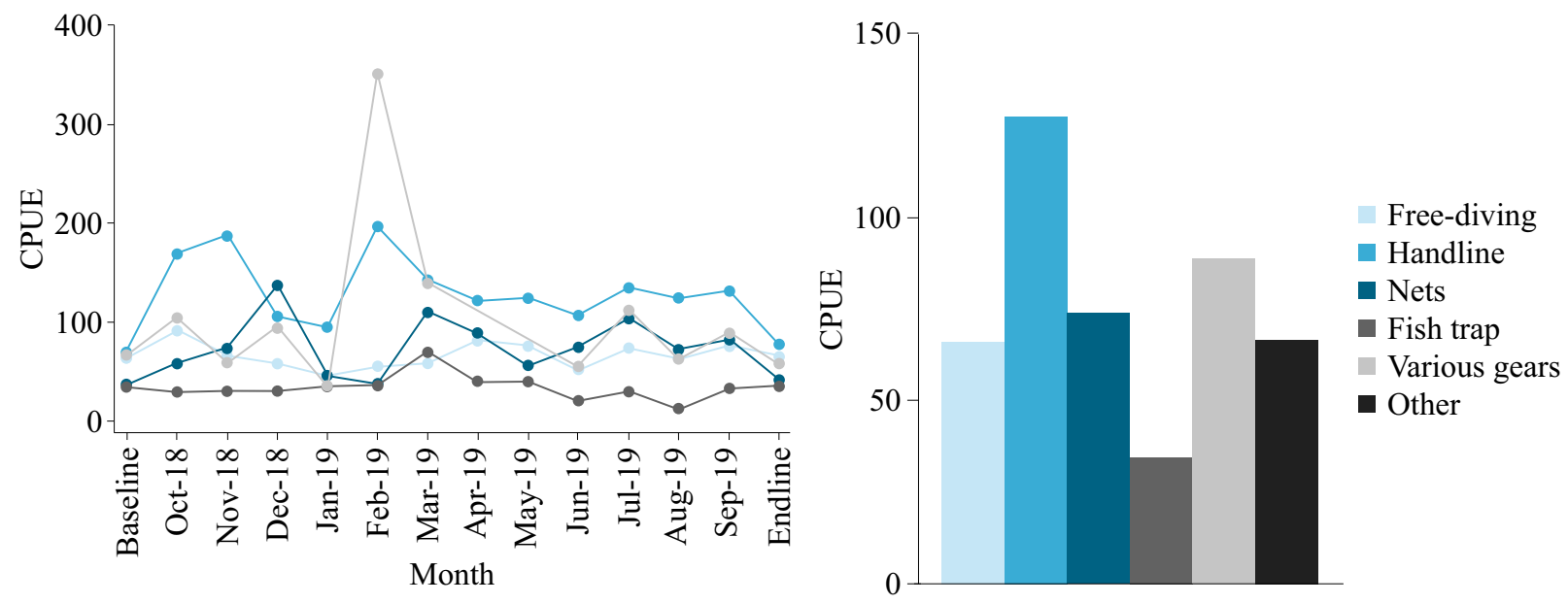

Figure 7. Catch per unit of effort (CPUE kg fisherman ${ }^{-1}$ month $^{-1}$ ) and total average by type of fishing gear.

Most fishers reported lobster as the most important species caught, followed by octopus and snapper. These species were associated with the coral-reef ecosystem, one of the most important ecosystems for fishing in Barú, as well as with the predominant fishing gear types among the F-hh, which were handlining and diving. There were at least other 15 species reported as captured but in lower proportions.

Three aspects to highlight: (i) fish traps and free-diving are fishing gear that target lobster; (ii) a great diversity of species is captured with handlining, notably snapper (Lutjanus), yellowtail snapper (Ocyurus chrysurus), great barracuda (Sphyraena barracuda), and bar jack (Carangidae); and (iii) nets are mainly used for bar jack and horse-eye jack (Caranx hipos, C. latus) (Figure 8).

\section{Non-labor strategies}

Non-labor strategies include income received from remittances and transfers from the state. On 


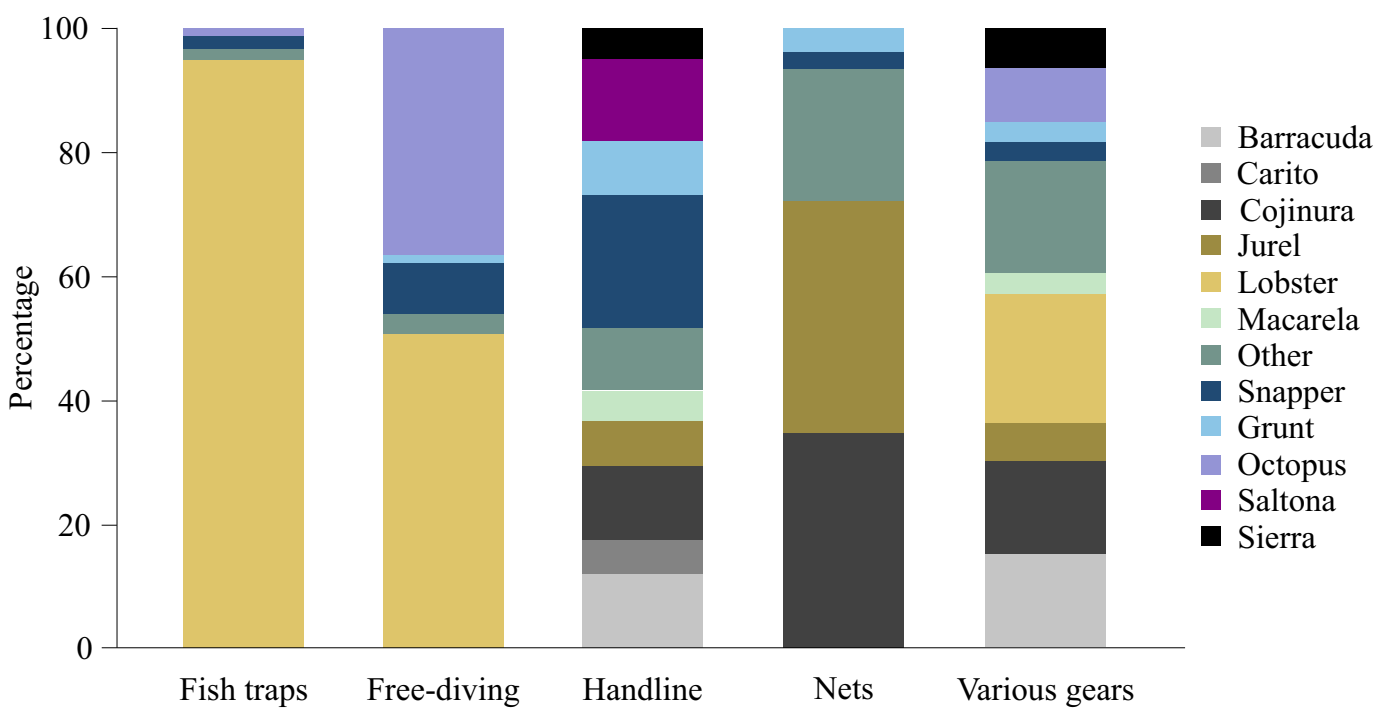

Figure 8. Main catch fish species by fishing gear.

average, $7.8 \%$ of non-F-hh and $14.8 \%$ of F-hh received subsidies. For these households, and respectively for non-F-hh and F-hh, these subsidies were associated with the conditional cash transfer program Familias en Acción (42.2\% and $24.8 \%)$, third-age subsidies $(45.8 \%$ and $75.9 \%)$ and compensation funds (15.7\% and 3.8\%). On the other hand, on average, $17.8 \%$ of F-hh and $7.8 \%$ of non-F-hh received income from remittances.

\section{Strategies for the use of financial capital}

The main use of informal and formal savings in the past, for both types of households, was to deal with unexpected or unforeseen events. Other uses were related to home improvements, education, property purchase, payments for boats or engines, and businesses, which account for $57 \%$ and $60 \%$ of the uses reported by non-F-hh and F-hh, respectively. Other reported uses included covering household expenses for food and health, general expenses, and debt repayment. Thirty six percent of households (38\% non-fishing and 33\% fishing) reported having no savings in the past.

In terms of use of savings during this study, on average, $18 \%$ of non-F-hh and $49 \%$ of F-hh reported using savings (formal and informal) in the month prior to the visit. The most common uses, for both types of households, were buying food and debt repayment. Moreover, about 95\% of households would like to allocate their savings to future investments such as education, home improvements, house purchasing, boats and vehicles acquisition, and independent business. On the other hand, the use of savings to cover contingencies was also considered important by $32 \%$ of non-F-hh and 39\% of F-hh.

Formal loans acquired in the past were mainly used for home improvements, business investment, and contingencies. Informal loans were used in the year prior to the survey by non-fishing and fishing households to cover immediate needs such as food ( $28 \%$ and $26 \%$ ), payment of debts (25\% and $15 \%)$, and contingencies (18\% and $22 \%$ ). Informal loans were also used to invest in businesses $(12 \%$ and $6 \%$ ), to purchase household items $(7 \%$ and $9 \%)$ or to make home improvements $(7 \%$ and $6 \%)$. During the period of the study, households continued asking for informal loans, used mainly to buy food (33\% in non-F-hh and $45 \%$ in F-hh), pay other debts (30\% in non-Fhh and $15 \%$ in F-hh) and cope with extraordinary events (13 and 7\% for non-F-hh and F-hh). 


\section{Allocation of consumption expenditures}

The monthly monetary expenditure of households in Barú was US\$ 785 US\$-PPP per month and was significantly higher for F-hh (US\$ 836) than for non-F-hh (US\$ 738). When the expenditure was calculated in per capita terms, this difference was no longer significant (US\$ 236 versus US\$ 222). When household size was scaled by the square root of number of members, the expenditure per capita was US\$ 430 for F-hh and US\$ 393 for non-F-hh.

As expected, there were some months in which expenses change. This pattern was similar for F-hh and non-F-hh (Figure 9). Particularly, in January expenditures increased significantly, probably due to the start of the school season and/or indebtedness during the holiday season and its associated expenses.

In terms of expenses composition, on average, $60 \%$ of household expenditure was allocated to food, including water, which represents $8.2 \%$ of total expenditure. Leisure and entertainment accounted for about $15-20 \%$ of expenses.

With regard to animal protein consumption, about $40 \%$ of expenses were used for white meat such as chicken and fish. However, for F-hh most of these expenses were aimed at chicken. The low figure related to the expenses on fish by F-hh did not mean that they consume less fish than nonfishing ones, as self-consumption plays an important role in terms of consumption. F-hh also consumed more milk than non-F-hh.

The frequency of consumption by type of animal protein (fish, seafood, chicken, beef, pork, or canned protein) was significantly higher in F-hh than in non-F-hh, although the proportion of monetary expenditure on protein was relatively equal for both types of households (Table 5). On average, F-hh consumed animal protein 10.3 times a week, while non-F-hh consumed it 7.6 times a week. This difference was statistically significant and was mainly defined by the higher consumption of fish and other seafood by F-hh. In a community such as Barú, households obtain fish for consumption not only from the market but also by catching it or receiving it as a gift. This consumption does not need a monetary exchange. The value of non-monetary consumption by non-F-hh -estimated at market prices- was similar to the value of fish they bought. For F-hh, the value of non-monetary consumption was up to eight to ten times the value of fish they bought.

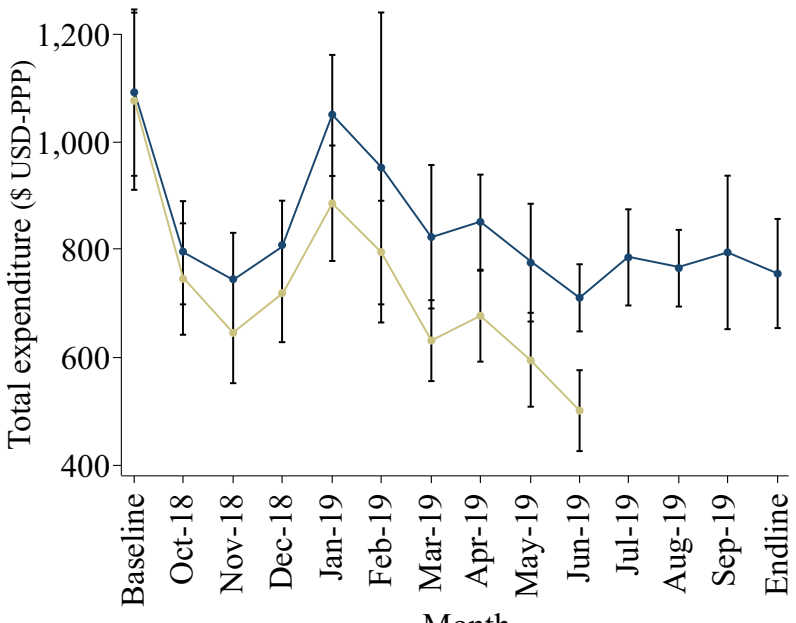

Month

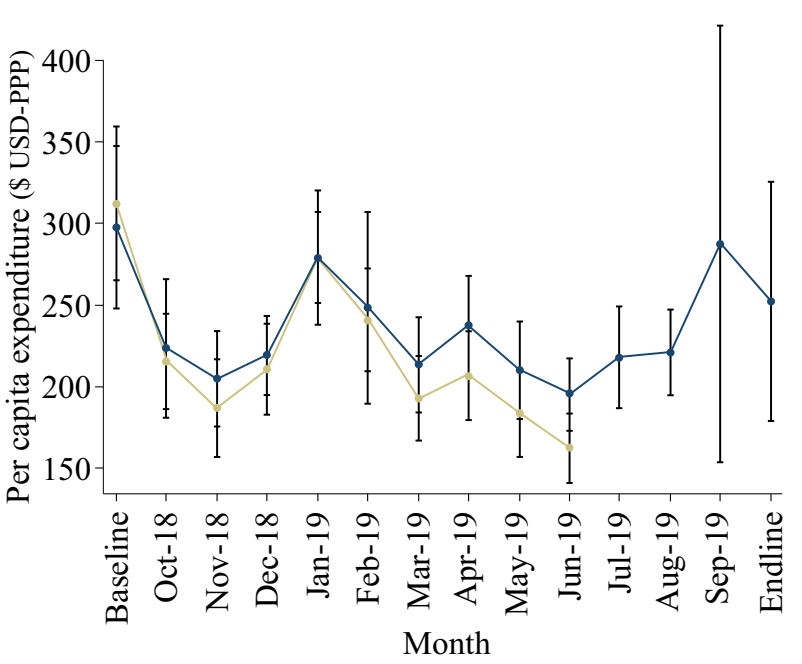

Month

Figure 9. Household total and per capita monetary monthly expenses. 
Table 5. Frequency of weekly animal protein consumption.

\begin{tabular}{|c|c|c|c|c|c|}
\hline \multirow[b]{2}{*}{ Type of protein } & \multicolumn{2}{|c|}{ Non-fishing households } & \multicolumn{2}{|c|}{ Fishing households } & \multirow[b]{2}{*}{ Difference (t-test) } \\
\hline & Observed & Mean (SD) & Observed & Mean (SD) & \\
\hline Fish & 1,454 & $2.47(3.06)$ & 1,307 & $4.38(2.67)$ & $-1.91^{*}$ \\
\hline Other seafood & 1,454 & $0.09(0.46)$ & 1,307 & $0.22(0.50)$ & $-0.13^{*}$ \\
\hline Chicken & 1,454 & $2.29(2.12)$ & 1,307 & $3.17(1.91)$ & $-0.88^{*}$ \\
\hline Beef & 1,454 & $1.26(1.52)$ & 1,307 & $0.95(0.95)$ & $0.31^{*}$ \\
\hline Pork & 1,454 & $1.32(1.60)$ & 1,307 & $1.31(1.07)$ & 0.01 \\
\hline Canned protein & 1,454 & $0.18(0.56)$ & 1,307 & $0.26(0.54)$ & $-0.08^{*}$ \\
\hline Total protein & 1,454 & $7.63(0.10)$ & 1,307 & $10.30(0.06)$ & $-2.67 *$ \\
\hline
\end{tabular}

$* \mathrm{p}<0.01$

\section{Food security strategies}

Strategies used by F-hh included going fishing (45.5\%), followed by asking family members for help, and reducing food consumption (27.3\%). In the case of non-F-hh, predominant strategies were reducing food consumption (47.1\%), asking relatives for help $(35.3 \%)$, or informal loans in shops (35.3\%) (Figure 10). However, 27\% of Fhh and $47 \%$ of non-F-hh facing a food shortage reported having to reduce the food of at least one member of the household; this difference between households was significant. Note that non-F-hh were the only ones that turned to moneylenders to solve food crises.

When some members of the household must reduce their food intake, in non-F-hh, it was either mainly women who did so or all members of the household equally, and, to a lesser extent, the head of the household. It was remarkable that in F-hh the main strategy was to reduce food for all members of the household equally, followed by the heads of household. In general, in the event of shocks affecting the availability of food, the most vulnerable groups in the household, i.e. children, were protected.

\section{Livelihood outcomes}

\section{Household income and expenditure}

Monthly monetary income, including labor and non-labor sources of F-hh was higher (US\$ 1,095 US\$-PPP) and relatively more stable over time compared to that of non-F-hh (US\$ 833 US\$PPP). Non-monetary income, estimated as the value of fish self-consumed at market prices, amounted to US\$ 50.47 US\$-PPP for F-hh and US\$ 0.68 US\$-PPP for Non-F-hh (Table 6).

On average, F-hh were better off than non-f-hh: US\$ 1,145 versus US\$ 834 US\$-PPP. Per-capita monthly income corresponded to US\$ 333 for Fhh and US\$ 255 for non-f-hh. When household size was scaled by the square root of total number of members, the monthly per capita income was US\$ 612 and US\$ 447 for fishing and non-fishing households, respectively (Figure 11).

For F-hh, 37\% of the income corresponded to income from fishing (monetary and non-monetary). Fish trade and gear rental generated an additional $6 \%$ of income for F-hh. For non-F-hh, fishing-related activities contributed with about $4 \%$ of income. The fishing sector contributed to about $20 \%$ of Barú's economy. However, this did 


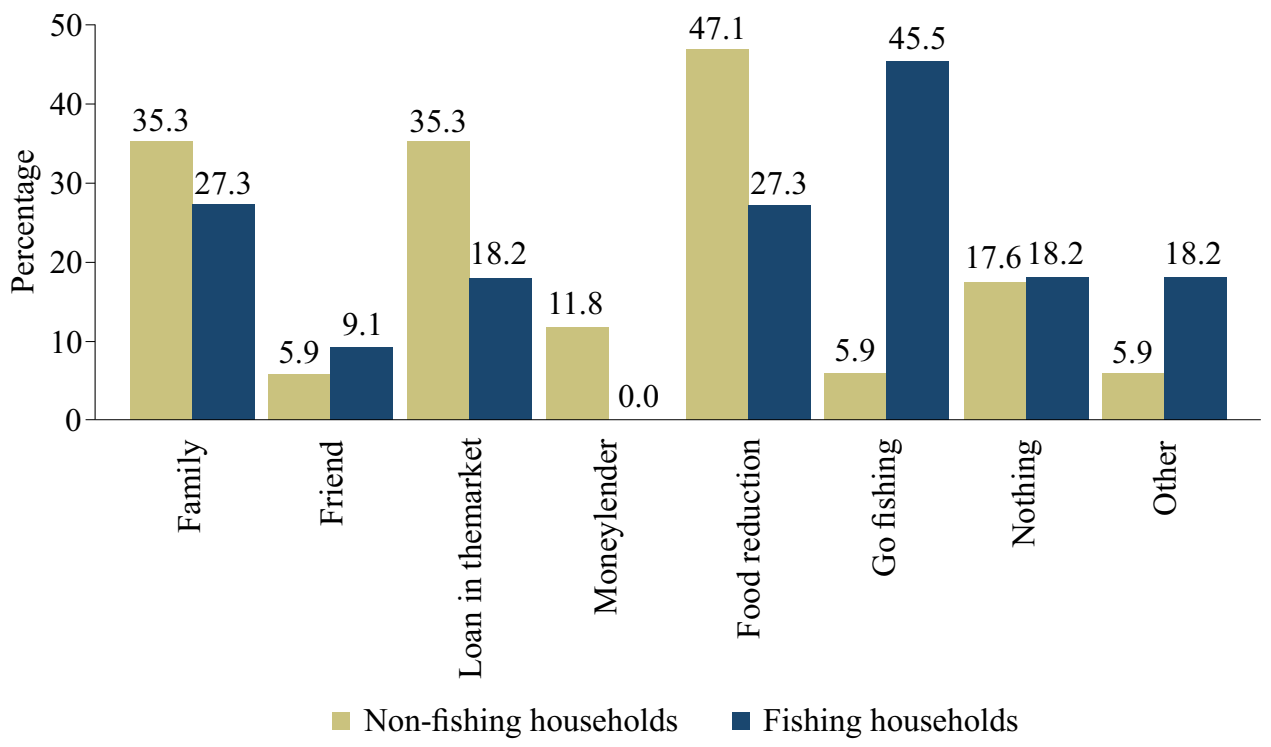

Figure 10. Household strategies to tackle food scarcity.

Table 6. Monthly income sources of households in Barú.

Household monthly income

From fishing

Labor different from fishing

Labor monetary income

Non-labor monetary income

Total monetary income

Non-monetary income from fishing

Monetary and non-monetary total income

not include the contribution of fishing activity to other activities such as the sale of food for tourism. The non-labor monetary income represented approximately $3.2 \%$ of the income of both households, without significant differences by type of household.

The average monthly income of a worker in Barú was US\$ 678 US\$-PPP, with significant sta-
Fishing households Percentage Non-fishing households Percentage

\begin{tabular}{rrrr}
374.75 & 33 & 0.97 & 0 \\
679.12 & 59 & 807.82 & 97 \\
$1,053.87$ & 92 & 808.79 & 97 \\
40.79 & 4 & 24.04 & 3 \\
\hline $1,094.66$ & 96 & 832.83 & 100 \\
\hline 50.47 & 4 & 0.68 & 0 \\
\hline $1,145.13$ & 100 & 833.51 & 100 \\
\hline
\end{tabular}

tistical differences between fishing and non-fishing households. On average, heads of households earned the highest labor income of any member of the household, averaging US\$ 745 US\$-PPP. The dynamics of income per worker during the study highlighted the importance of holiday seasons (December-January and June-August), particularly for F-hh, whose income increases at these times 


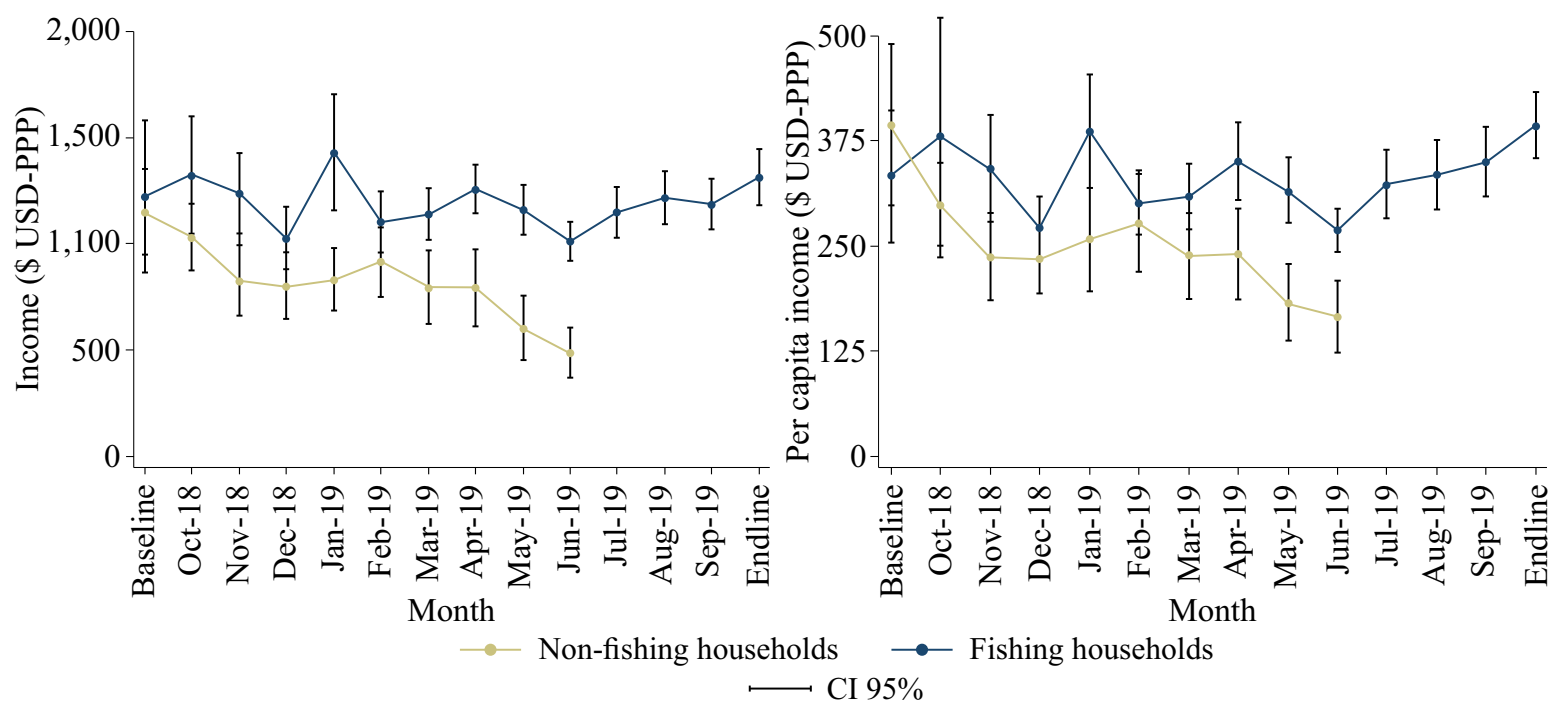

Figure 11. Total monthly household income (left) and total monthly per capita income (right).
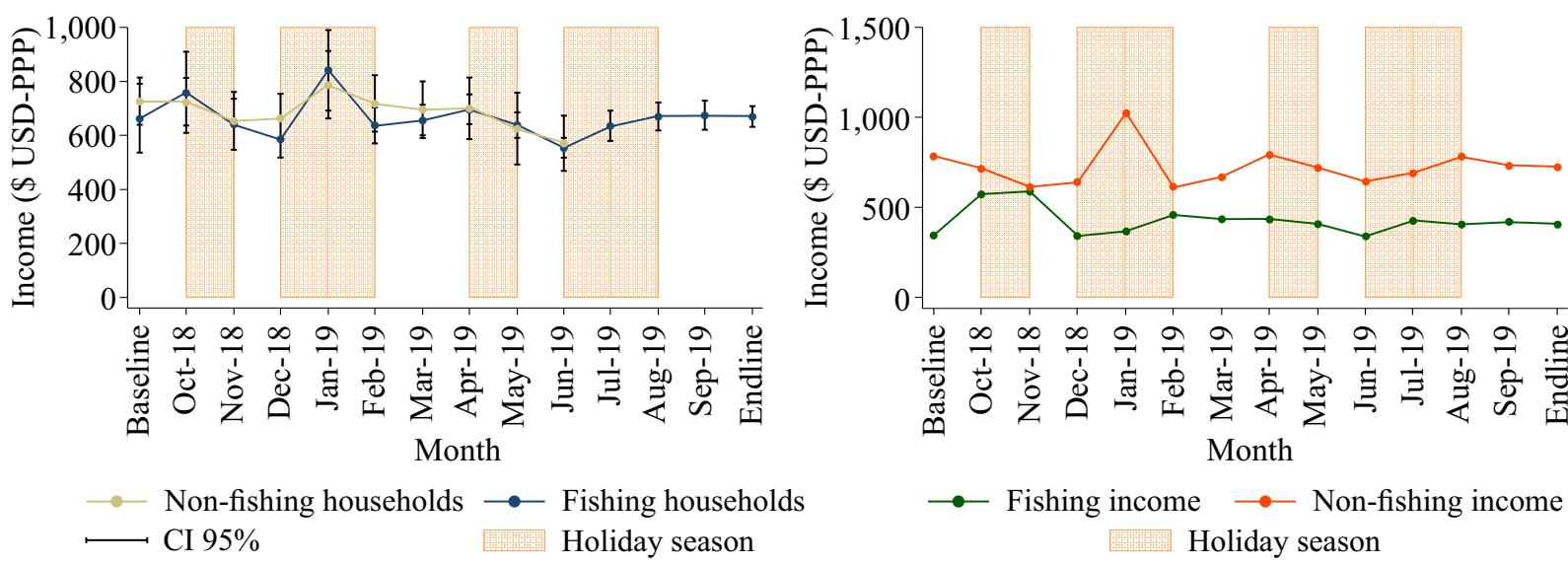

Figure 12. Labor income by worker per month (left panel) and fishing-related income for fishing households (right panel).

in terms of total labor income (Figure 12, left panel), mainly driven by fishing-related activities (Figure 12, right panel). A correlation analysis between the two series of income from fishing and income from other seasons shows a significant value of -0.2655 , which suggest a substitution effect between fishing and non-fishing sources of income. Expenditure and income trends exhibited a similar tendency: when income increases (decreases), expenditure also increases (decreases) (Figure 13). This suggests that households may have had a surplus that allowed them to save. However, costs associated with productive inputs were not included in this analysis for either fishing households or non-fishing ones.

\section{Food security}

Results from our adapted indicator of food security indicated that $60 \%$ of households could be classified as food secure, and only a small fraction of households could be considered in moderate or severe food insecurity (Figure 14). 


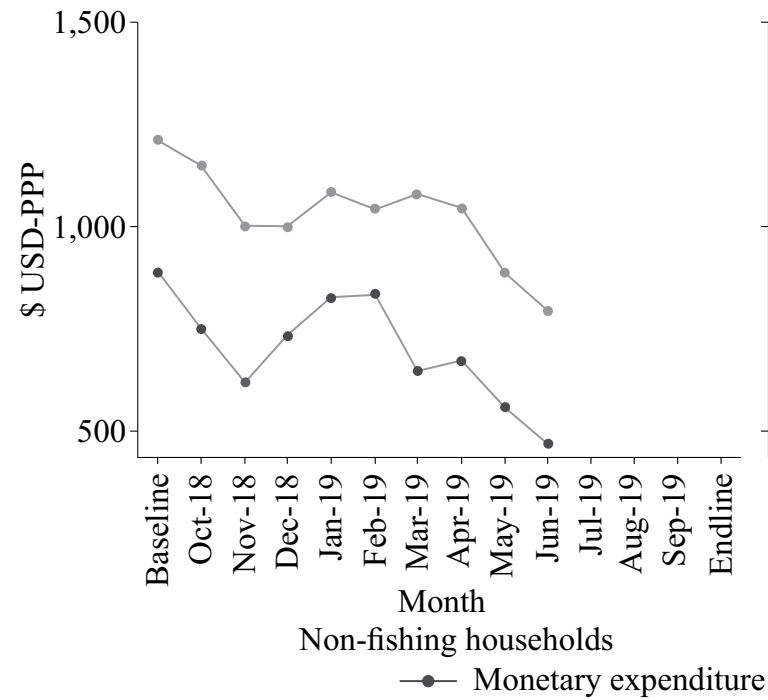

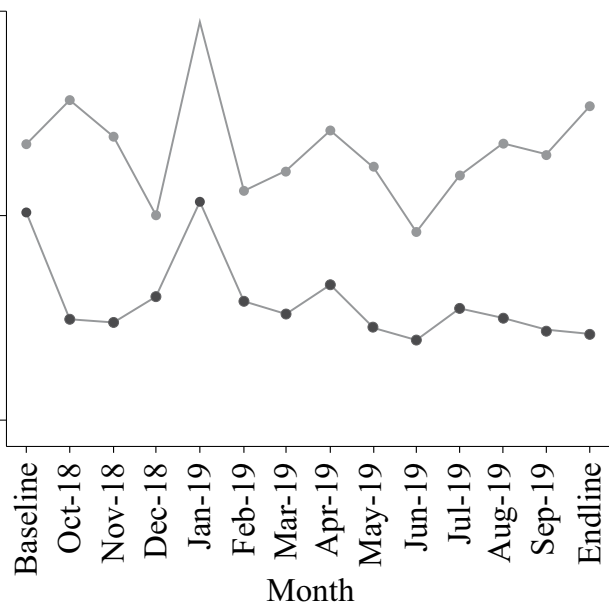

Fishing households

Figure 13. Total monthly income and total monthly expenditure by type of household.

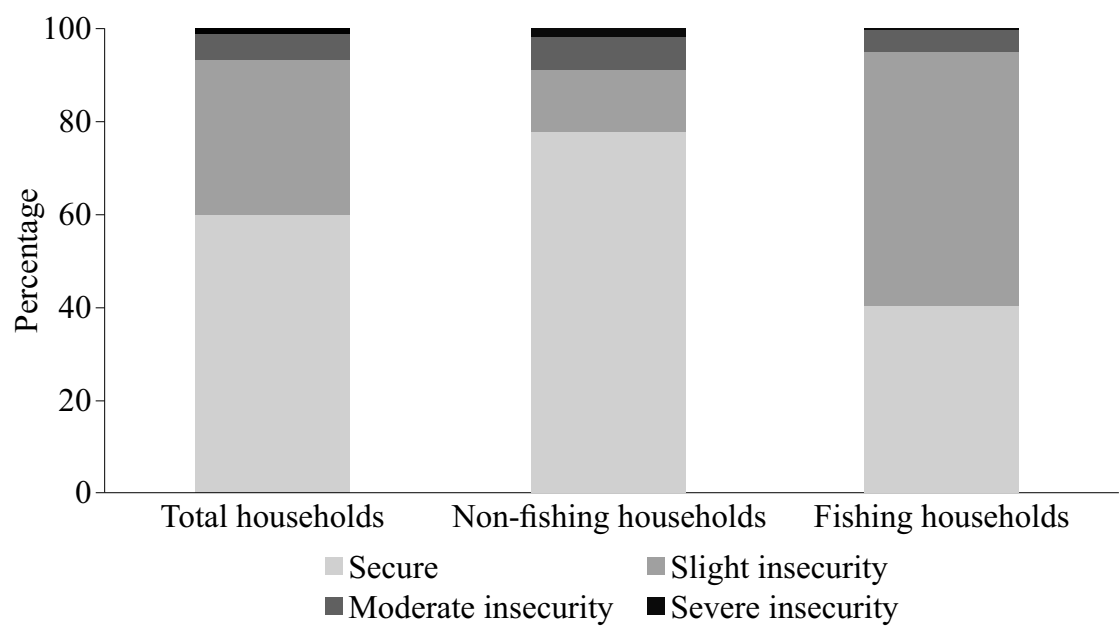

Figure 14. Annual average of types of food insecurity calculated by adapting the Latin American and Caribbean Food Security Scale (ELCSA) (FAO 2012).

None of the F-hh were in severe insecurity and there were fewer F-hh than non-F-hh in moderate insecurity. However, the slight food insecurity was much greater in F-hh. Given that they have access to fish for solving their food needs this result did not seem intuitive. The main source of slight insecurity in F-hh was related to the variation in diet, while the other sources of insecurity decreased over time (Figure 15).
To explore the relationship between fish that has been gifted and household food insecurity, a correlation analysis showed that the higher the level of food insecurity the greater the probability of receiving gifted fish (Table 7).

\section{Poverty}

According to the national poverty lines, a household is considered in poverty if its income 


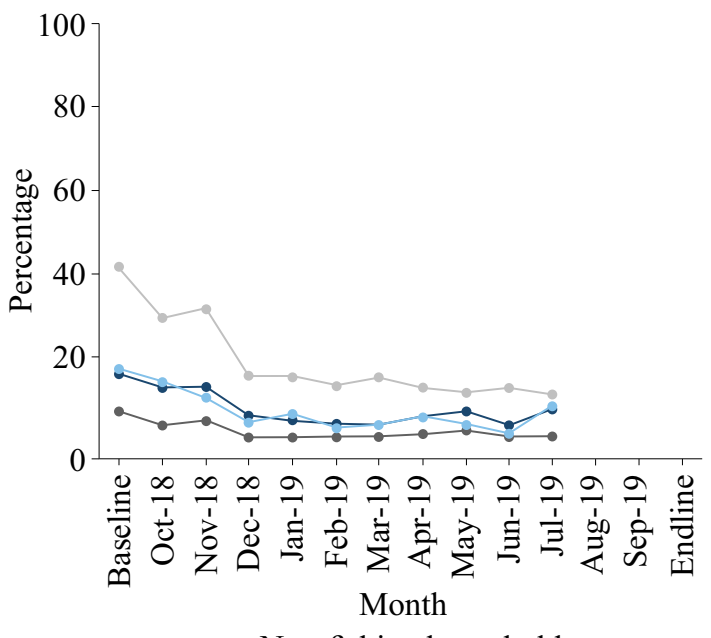

Non-fishing households

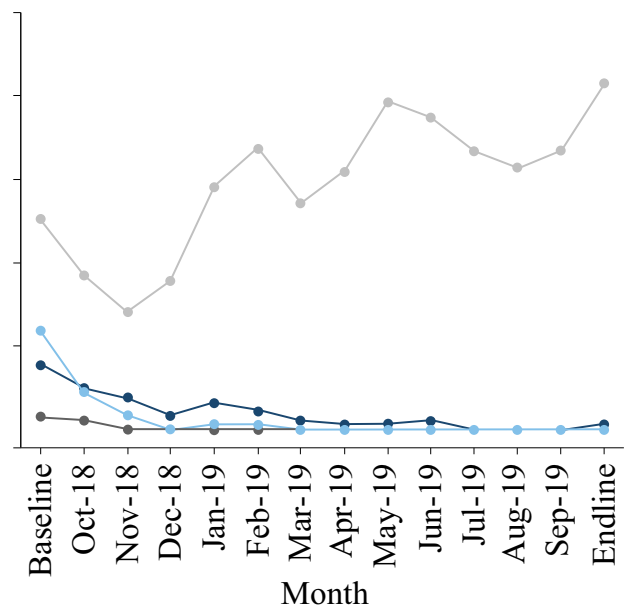

Fishing households

$\longrightarrow$ Could not vary food

$\longrightarrow$ Had to reduce food portions

- Someone went to bed hungry

- Someone could not have breakfast, lunch or dinner

Figure 15. Types of food insecurity according to the adapted scale from the Latin American and Caribbean Food Security Scale (ELCSA) (FAO 2012).

Table 7. Correlation between food insecurity level and receiving fish as a gift.

Food insecurity

Secure

Slight insecurity

Moderate insecurity

Severe insecurity

${ }^{*} \mathrm{p}<0.01$

is lower than US\$ 180 US\$-PPP and under extreme poverty if it is lower than US\$ 82 US\$PPP (DANE 2018). The headcount poverty index for Barú was similar to that of the department where it was located and higher than the national level (Table 8). However, in terms of monetary poverty, F-hh were much better off than non-F$\mathrm{hh}$, and these differences were statistically significant. Extreme poverty of non-F-hh was much higher than the national level, while that for F-hh was lower than the department and the national levels.

\section{Inequality}

Non-F-hh exhibit higher measures of inequality than F-hh for all the dimensions studied (Table 9). The Gini index for Barú's total income was 0.423 , which was lower than that reported for the Bolivar department (0.472) and for the country (0.517). Labor income presented the highest levels of inequality in non-F-hh, while in F-hh the source of greatest inequality was non-labor income (subsidies, remittances, and interest payments). For the total sample, the coefficients showed that non-labor income was also the source of greatest inequality.

\section{Potential effects of fishing activity on sustainable} use

According to the proportion of gear types used in Barú, the fishing gear used in Barú has a mod- 
Table 8 . Headcount monetary poverty index by household, total, local and national (indicators for Barú are from the average of all survey months).

\begin{tabular}{lccccc}
\hline & $\begin{array}{c}\text { Non-fishing } \\
\text { households }\end{array}$ & $\begin{array}{c}\text { Fishing } \\
\text { households }\end{array}$ & $\begin{array}{c}\text { Total } \\
\text { households }\end{array}$ & $\begin{array}{c}\text { Bolívar } \\
\text { department }\end{array}$ & Colombia \\
\hline Poverty line & 51.2 & 27.1 & 38.3 & 36.2 & 27.0 \\
Extreme poverty line & 29.4 & 4.5 & 16.1 & 7.0 & 7.2 \\
\hline
\end{tabular}

Table 9. Gini coefficient for household income and expenditure.

\begin{tabular}{lccc}
\hline Gini measures & Non-fishing households & Fishing households & Total households \\
\hline Labor income & 0.560 & 0.258 & 0.421 \\
Non-labor income & 0.524 & 0.511 & 0.516 \\
Total income & 0.513 & 0.308 & 0.406 \\
Per capita income & 0.532 & 0.322 & 0.423 \\
Expenditure & 0.327 & 0.270 & 0.333 \\
\hline
\end{tabular}

erate to low effect on the ecosystem. The most harmful effects were associated with size selection, species selection, and incidental mortality (Table 10). However, the fishing gear in general has high energy efficiency, low generation of ghost fishing, high catch quality (no agglomeration or decomposition that damages the catch), and few effects on the species' habitats moderate to low effect on the ecosystem (Figure 16).

\section{DISCUSSION}

The main purpose of this study was to characterize the livelihoods of SSF communities, in particular, assets, strategies, and livelihood outcomes of fishing and non-fishing households in a community in the Colombian Caribbean. Our results show the differentiated strategies that F-hh and non-F-hh follow to develop their livelihoods given their human, social and financial capital endowments.
Households in this community differ in their illiteracy rate, which is about seven percentage points greater for fishing than non-F-hh, and even greater if only the heads of household are considered. Non-F-hh heads are more highly educated than those from F-hh, by about a year and a half. In general, those individuals whose main activity is fishing report significantly lower levels of education than the sample's average employed population. These results coincide with data from the DANE (2018) household survey, which indicates that half of the people involved in fisheries and aquaculture have reached no further than basic primary education and that about one-fifth are illiterate (OECD 2016). Moreover, these findings could confirm the point raised by Béné et al. (2016), who argue that fishing is an activity associated with low human capital. However, fishing does require higher physical and psychological efforts given the strenuous, dangerous, and uncertain related labor journeys. F-hh that are less endowed in terms of education see fishing as the only alternative for income generation. 


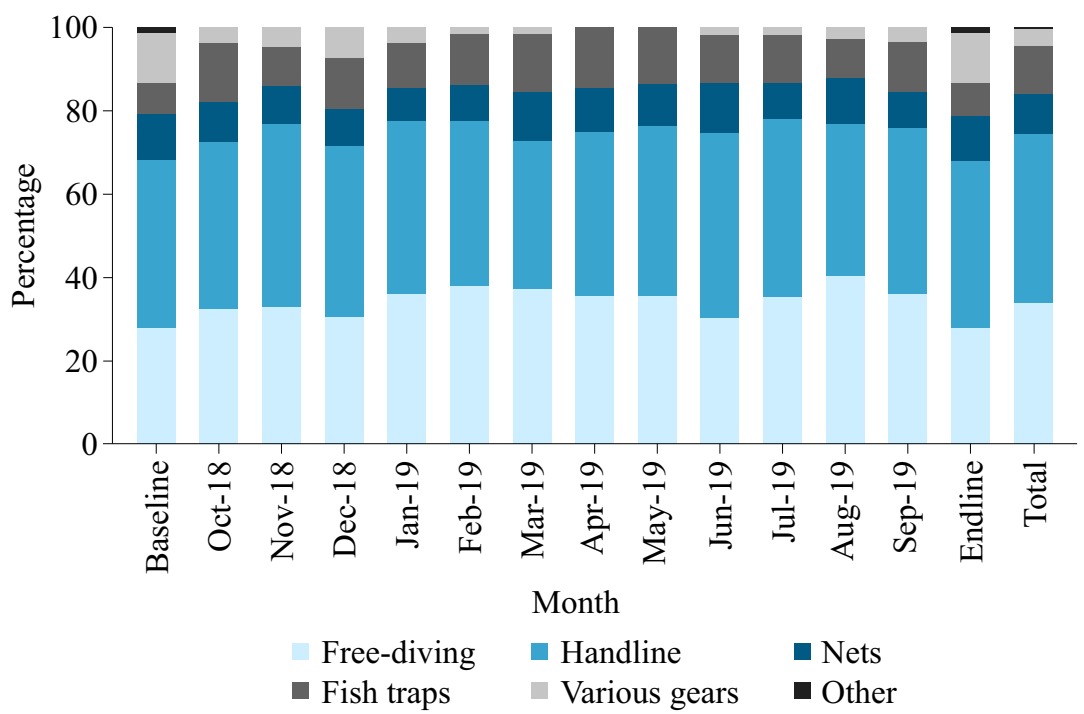

Figure 16. Percentage of fishers using each type of fishing gear.

Table 10. Estimation of the effects of the different fishing methods on the marine ecosystem of Barú (Bjordal 2005).

\begin{tabular}{lcccccccc}
\hline & $\begin{array}{c}\text { Size } \\
\text { selection }\end{array}$ & $\begin{array}{c}\text { Species } \\
\text { selection }\end{array}$ & $\begin{array}{c}\text { Incidental } \\
\text { mortality }\end{array}$ & $\begin{array}{c}\text { Ghost } \\
\text { fishing }\end{array}$ & $\begin{array}{c}\text { Effects on } \\
\text { the habitat }\end{array}$ & $\begin{array}{c}\text { Energy } \\
\text { efficiency }\end{array}$ & $\begin{array}{c}\text { Catch } \\
\text { quality }\end{array}$ & $\begin{array}{c}\text { Ecosystem } \\
\text { effect index }\end{array}$ \\
\hline $\begin{array}{l}\text { Hook fishing or } \\
\text { handlining, longline, } \\
\text { pinel, rope }\end{array}$ & $5(2.3)$ & $4.5(2.0)$ & $6(2.7)$ & $9.5(4.3)$ & $8.5(3.8)$ & $8.5(3.8)$ & $8.5(3.8)$ & $7.2(3.3)$ \\
$\begin{array}{l}\text { Diving } \\
\text { Fishing net }\end{array}$ & $8(2.7)$ & $9(3.1)$ & $5(1.7)$ & $10(3.4)$ & $10(3.4)$ & $8(2.7)$ & $9(3.1)$ & $8.4(2.9)$ \\
Pot fishing (traps) & $2(0.2)$ & $3(0.3)$ & $5(0.5)$ & $3(0.3)$ & $7(0.7)$ & $8(0.8)$ & $5(0.5)$ & $4.7(0.5)$ \\
\hline Total & $7(0.7)$ & $7(0.7)$ & $9(1.0)$ & $3(0.3)$ & $8(0.9)$ & $8(0.9)$ & $9(1.0)$ & $7.3(0.8)$ \\
\hline
\end{tabular}

Our results also suggest that things are changing for new generations: (i) young people might be less interested in fishing activity than their parents, and (ii) F-hh are currently investing more in human capital. In fact, some of the households initially classified as fishing ones reported not fishing during the survey implementation.

The estimated rate of people not in education, employment, or training (NEET) is twice as high in Barú as that reported nationally, showing the scarce opportunities young people have in rural and fishing communities. For women, this rate is even higher: seven out of every 10 women in this age range are neither working nor studying.

Although the average household size is similar between fishing and non-F-hh, F-hh tend to have more people working. In addition, F-hh in Barú exhibit higher occupational diversity, likely because of the uncertainty associated with fishing. F-hh diversify significantly more than non- 
fishing ones; not all members of F-hh fish, but this activity is their highest source of income. Our findings are consistent with Béné and Friend (2011), who argue that fishing is part of a diversified matrix of livelihood activities, where fishingrelated activities remain the most important source of income.

According to Ellis and Allison (2004), livelihood diversification reduces the poor's vulnerability to food insecurity, reduces dependence on natural resources, and can provide the basis for building assets that allow households to design their own exit strategies from poverty. It also improves human capital by providing skills and experience. However, the benefits of diversification are often inhibited by the local context and governance, as well as other barriers to trade and mobility (imperfect and restricted markets). For example, access to land and agriculture, as well as access to financial services, plays a significant role in livelihood diversification and household food security (Ellis and Allison 2004). In Barú, strong limitations on the potential for diversification were found. For example, even though the vast majority of households surveyed are part of native families, only six households in the sample report having land for farming. This is caused by the displacement brought about by tourism on the island at the natural park. In this sense, agricultural and livestock activities are exceptional. The main sources of income diversification are the provision of services, mainly related to tourism and construction. Our findings also show that financial services are imperfect and restricted for households in fishing communities. Although Fhh save informally much more than non-fishing ones, only $10 \%$ of F-hh save in a formal financial institution and more than $60 \%$ report shark loans from informal money lenders, which might lead them to path dependence: asking for a loan to cover the previous one.

In general, the community of Barú faces restrictions in terms of access to different forms of capital, such as land, education, or financial capital, which makes it difficult to participate in diversified labor markets. These restrictions seem to be more important for the fishers, who are older and have lower education levels.

For those in Barú who fish as a secondary activity, fishing is a coping strategy when faced with shocks. In that sense, given the semi openaccess nature of the resource, fishing in Barú could provide a means of producing income both as a safety net, to deal with transitory or shortterm poverty, and as last-resort activity, associated mostly with chronic or long-term poverty (Béné 2004; Béné et al. 2007).

With respect to food security, SSF have been recognized as a key to improving food security in developing countries, particularly for those whose livelihoods depend on them (Kawarazuka and Béné 2010). We found that the frequency of animal-protein consumption is significantly higher in F-hh than in non-F-hh, although the proportion of monetary expenditure on protein is relatively equal for both. However, the estimated value of fish consumption at market prices is almost twofold for F-hh than for non-F-hh, which reflects the importance of self-consumption. In other words, F-hh enjoy a diet with higher protein content for the same amount of monetary expenditure. Consistent with other studies, we found that fishing is a source of food security for the community (Gomna and Rana 2007; Chamnan et al. 2009; Mujinga et al. 2009).

The proportion of fish left by households for home consumption varies among communities and depends on the fishery in which it is being managed: from $11-20 \%$ in Papua New Guinea (Friedman et al. 2008) to $74.5 \%$ in Lao PDR (Garaway 2005). Generally, the poorest households rely more on subsistence consumption of fish, compared to better-off households with more access to markets. However, some studies by Béné (2003), in Lake Chad, show that the poorest households consume less of their own catch and sell most of it to generate income and buy cheaper food. 
In Barú, 13\% of fish caught is destined for selfconsumption. This strategy allows the F-hh in Barú to report less cases of having to reduce food portions at home, having to send someone to sleep hungry, or having to miss a meal. Chanman et al. (2009) discuss the characteristics of fish for self-consumption: (i) smaller fish containing more nutrients; (ii) smaller fish easier to distribute among household members; (iii) species available year-round; and (iv) typically consumed whole, which improves micronutrient provision. However, F-hh in Barú face a restriction in terms of variety of food, affecting this dimension of food security.

When having to deal with income shocks affecting food security, fishing appears to be a coping strategy for F-hh to deal with food shocks. Fishing strategy is then a safety net to cover immediate food needs (Béné et al. 2007, 2016). As argued by Kawurazuka and Béné (2010), fishing is found to play a double role in Barú: (1) as an income-generating activity or cash crop; (2) as a food-generating activity or food crop. Thus, fishing is not only important in terms of improving food security per se, but also as an incomegenerating activity that improves livelihoods, including nutrition.

It was found that $2 \%$ of caught fish is given as a gift to other households. Further, nearly onethird of the fishers give fish as a gift and nearly one-third of households receive fish as a gift, particularly those in the worst conditions in terms of food security. This result suggests that fishers were able to focus gift efforts on the population that was most in need, playing an important role in solving extreme food insecurity. Those findings show a support network and altruistic behavior within this community.

A growing number of studies suggest that the income of F-hh is often higher than that of non-Fhh (Thorpe et al. 2007). Other literature points that artisanal fishers rank among the lowest income groups or below national income levels (Herring and Racelis 1992; Willmann 2004; Teh and Sumaila 2007). Similarly to our results, Allison (2005), Mkenda (2000) and Tietze et al. (2000) found that income of F-hh is higher than that of non-F-hh in rural communities. Despite studies showing higher incomes in F-hh compared to other rural households, Thorpe et al. (2007) highlighted that monetary income cannot be seen as the only way to measure household poverty. This assertion is even more important in the case of isolated communities where access to education, health or basic services is severely restricted, resulting in health, housing, or sanitation problems (Béné 2003). In our case, at the time of the study, the Barú community did not have access to basic services such as health, drinkable water, or sewage.

One of the most important findings of this study is that the poverty and extreme poverty levels of F-hh are lower than those of non-F-hh. Despite strong restrictions faced by F-hh in terms of access to different forms of capital (education, financial services, land), access to natural capital and higher diversification provide them with income to solve basic needs and resources to reduce food insecurity. The poverty figures for Fhh are similar to national levels, while the figures for extreme poverty are better for F-hh than they are for the national average. This shows the importance of fishing as a buffer in against the vulnerability of rural poor households.

The results also suggest that restrictions on fishing for these communities, without providing alternative income earning alternatives or social protection programs, could result in deterioration of their living conditions. In fact, our findings show that non-labor monetary income (mainly subsidies and transfers) represents only $3.2 \%$ of the income of both types of households. Prohibitions on fishing would require, for example, nonconditional or conditional- conservation cash transfers and other social protection programs allowing households to cope with the effect of not fishing on income and food security. On the other hand, as proposed by Cinner et al. (2009), 'wealth 
generation and employment opportunities directed at the poorest fishers may help reduce fishing effort on overexploited fisheries'.

Although Barú is located next to a protected area, where it is only allowable to fish for subsistence, the currently used fishing gear suggests moderate to low impact activity. Although the fishing volumes are low compared to the world average in small fisheries, it is not possible to say anything about the sustainability of the catch from the survey data, because biological data on the abundance of fish are required. However, the species more frequently exploited in Barú lack of information about conservation status. Lobster, some species of snapper and horse mackerel are classified as vulnerable (Chasqui-Velasco et al. 2017; PNN 2019), while barracuda and garfish are catalogued as near-threatened (Fishbase [www.fishbase.de], Chasqui-Velasco et al. 2017). Results of the socio-demographic characterization confirm our hypotheses and coincide with findings presented in the literature on SSF around the world. As highlighted by Ellis and Allison (2004) and Beck and Nesmith (2001), the landless rural poor are among the most vulnerable groups and basically depend on wage labor and the extraction of common-pool resources. In the ancestral community of Barú, residents have been dispossessed of land due to increased tourism during the last 30 years. Livelihood systems in Barú are strongly linked to the extraction and use of natural capital, they are associated with ethnic minorities settled in areas that are strategic for the conservation of biodiversity, and they make use of common pool resources due to their lack of access to land and limited opportunities for income development. Hence, employment, productive, and capacity-building interventions allowing to diversify sources of income, as well as conservation strategies and even the assignment of property rights to use resources, would promote livelihood sustainability. Ultimately, strict conservation strategies must be developed once the external constraints, leading these com- munities to resource extraction and overexploitation are removed. Although there is low community participation in the management of local fisheries or the marine protected area at present, they are now more visible to the authorities, thanks to the consolidation of organizations and local councils. Future measures for conservation and fisheries management should consider the community's input and participation.

\section{ACKNOWLEDGEMENTS}

The authors gratefully acknowledge research funding and editorial support from the Swedish International Development Cooperation Agency (SIDA) through the Environment for Development (EfD) initiative at the University of Gothenburg. The study was done as part of the Research Group on Environmental, Natural Resource and Applied Economics Studies based at Universidad de Los Andes, Colombia.

We express our thanks to all the households which participated in this study, answering the surveys every month for more than a year. We are also thankful to the co-researchers of the project, particularly to Enrique Villamil, who accompanied the project in Barú all the time and taught us a lot about fishing and the people of Barú. We also recognize the translation support from Tiziana Laudato and editorial support from Cyndi Berck.

\section{REFERENCES}

Agudelo E, Ajiaco RE, Álvarez L, Agudelo E, Ajiaco RE, Álvarez LE, Barreto CG, Borda CA, Bustamante CC, Caldas JP, et al. 2011. Protocolo de captura de información pesquera, biológica y socioeconómica en Colombia. Ministerio de Agricultura y Desarrollo Rural, Dirección de Pesca y Acuicultura, 
Subgerencia de Pesca y Acuicultura INCODER. Conservación Internacional. $80 \mathrm{p}$.

AlLison EH. 2005. The fisheries sector, livelihoods and poverty reduction in Eastern and Southern Africa. In: Ellis F, FreEman HA, editors. Rural livelihoods and poverty reduction policies. Routledge, London.

Allison EH, Ellis F. 2001. The livelihoods approach and management of small-scale fisheries. Mar Policy. 25: 377-388.

AsiedU B. 2011. Understanding the socioeconomic characteristics and perception of poverty in artisanal fisheries of Ghana. The Case of Kpong Reservoir, Munich, GRIN Verlag. https://www.grin.com/document/165448.

Bailey C, Jentoft S. 1990. Hard choices in fisheries development. Mar Policy. 14 (4): 333344. doi:10.1016/0308-597X(90)90055-V

Barr R, Bruner A, Edwards S. 2019. Fisheries Improvement Projects and small-scale fisheries: The need for a modified approach. Mar Policy. 105: 109-115.

BARro R, LEE J. 2013. A new data set of educational attainment in the world, 1950-2010. J Dev Econ. 14: 184-198.

Beck T, Nesmith C. 2001. Building on poor people's capacities: the case of common property resources in India and West Africa. World Dev. 29 (1): 119-133.

BÉNÉ C. 2003. When fishery rhymes with poverty: a first step beyond the old paradigm on poverty in small-scale fisheries. World Dev. 31 (6): 941-75.

BÉNÉ C. 2004. Contribution of small-scale fisheries to rural livelihoods in a water multi-use context with a particular emphasis on the role of fishery as a "last resort activity" for the poor. Background paper prepared for the Second Session of the Working Party on SmallScale Fisheries, Bangkok, Thailand, 18-21 November 2003. Rome: FAO. 31 p.

BÉNÉ C. 2009. Are fishers poor or vulnerable? Assessing economic vulnerability in smallscale fishing communities. J Dev Stud. 45 (6):
911-933. doi:10.1080/00220380902807395

Béné C, Arthur R, Norbury H, Allison EH, Beveridge M, Bush S, Campling L, Leschen W, Little D, Squires D. et al. 2016. Contribution of fisheries and aquaculture to food security and poverty reduction: assessing the current evidence. World Development. 79: 177-196. doi: 10.1016/j.worlddev.2015.11.007 BÉNÉ C, FRIEND RM. 2011. Poverty in small-scale fisheries: old issue new analysis. Prog Dev Stud. 11 (2): 119-144.

Béné C, McFadyen G, Allison EH. 2007. Increasing the contribution of small-scale fisheries to poverty alleviation and food security. FAO Fish Tech Pap. 481.

BJORDAL $\AA$. 2005. Uso de medidas técnicas en la pesca responsable: regulación de artes de pesca. En: Guía del administrador pesquero. Medidas de ordenación y su aplicación. FAO Fish Tech Pap.

Chambers R, Conway GR. 1992. Sustainable rural livelihoods: practical concepts for the 21st century. IDS Discussion Paper 296 (September).

Chamnan C, Thilsted S, Roitana B, Sopha L, Gerpacio RV, Roos N. 2009. The role of fisheries resources in rural Cambodia: combating micronutrient deficiencies in women and children. Department of fisheries post-harvest technologies and quality control. Fisheries Administration, Ministry of Agriculture, Forestry and Fisheries. Phnom Penh.

Chasqui-Velasco L, Polanco FA, Acero P, Mejía-Falla PA, Navia A, Zapata LA, CalDAS J, editors. 2017. Libro rojo peces marinos de Colombia (2017). Instituto de Investigaciones Marinas y Costeras Invemar, Ministerio de Ambiente y Desarrollo Sostenible. Serie de Publicaciones Generales de INVEMAR. 93. Santa Marta, $552 \mathrm{p}$.

CINNER JE. 2014. Coral reef livelihoods. Curr Opin Environ Sustain. 7: 65-71.

Cinner JE, Daw T, McClanahan TR. 2009. Socioeconomic factors that affect artisanal 
fishers' readiness to exit a declining fishery. Conservation Biol. 23 (1): 124-30.

Cinner JE, McClanahan TR, Graham NAJ, Daw TM, Maina J, Stead SM, Wamukota A, BROWN K, Bodin O. 2012. Vulnerability of coastal communities to key impacts of climate change on coral reef fisheries. Global Environ Change. 22 (1): 12-20.

Cinner JE, McClanahan TR, Wamukota A. 2010. Differences in livelihoods, socioeconomic characteristics, and knowledge about the sea between fishers and non-fishers living near and far from marine parks on the Kenyan coast. Mar Policy. 34 (1): 22-28. doi:10.1016/ j.marpol.2009.04.003

[DANE] DePartamento Administrativo NacioNAL DE Estadísticas. 2018. Boletín Técnico Pobreza Monetaria en Colombia. https://img. lalr.co/cms/2018/03/22191631/bol_pobreza_ 17.pdf.

DFID. 1999. Sustainable livelihoods guidance sheets introduction: overview. Sustainable Livelihoods Guidance Sheets 10.

Ellis F, Allison E. 2004. Livelihood diversification and natural resource access. LSP Working Paper 9. Food and Agriculture Organization of the United Nations. Livelihood Support Programme (LSP).

Etea BG, Zhou D, Abebe KA, Sedebo DA. 2019. Household income diversification and food security: evidence from rural and semiurban areas in Ethiopia. Sustainability. 11. 3232. doi:10.3390/SU11123232

[FAO] Food ANd Agriculture Organization OF the United Nations. 2012. Escala Latinoamericana y Caribeña de Seguridad Alimentaria.

[FAO] FoOd AND Agriculture ORganization OF the United NAtions. 2021. Small-scale fisheries and the human right to adequate food Making the connection: exploring synergies in the implementation of the SSF Guidelines and the Right to Food Guidelines. Rome. doi:10.4060/cb4939en
FAO, World Fish Center. 2008. Small-scale capture fisheries: a global overview with emphasis on developing countries a preliminary report of the Big Numbers Project. The WorldFish Center. Penang, Malaysia. In The World Bank. Global Program on Fisheries (PROFISH). 63 p.

Friedman K, Krone M, Pinca S, Magron F, Boblin P, Pakoa K, Awiva R, Chapman L. 2008. Papua New Guinea country report: profiles and results from survey work at Andra, Tsoilaung, Sideia and Panapompom. Pacific Regional Oceanic and Coastal Fisheries Development Programme, New Caledonia.

GARAWAY C. 2005. Fish, fishing and the rural poor. A case study of the household importance of small-scale fisheries in the Lao PDR. Aquat Resour Cult Dev. 1 (2): 131-144.

GARCíA CB. 2010. Conocimiento tradicional: 1o que los pescadores artesanales del Caribe colombiano tienen para decirnos. Pan Am J Aquat Sci. 5 (1): 78-90.

GOMNA A, RANA K. 2007. Inter-household and intra-household patterns of fish and meat consumption in fishing communities in two states in Nigeria. Br J Nutr. 97 (1): 145-152.

HerRing A, Racelis R. 1992. Monitoring the coverage of public programs on low-income families: Philippines 1992, Integrated Development Planning Project, National Economic Development Authority, Manila.

KAWARAZUKA N. 2010. The contribution of fish intake, aquaculture, and small-scale fisheries to improving nutrition: a literature review. The WorldFish Center Working Paper. 2106. The WorldFish Center, Penang, Malaysia. 44 p.

KAWARAZUKA N, BÉNÉ C. 2010. Linking smallscale fisheries and aquaculture to household nutritional security: an overview. Food Sec. 2: 343-357. doi:10.1007/s12571-010-0079-y

LizARAzo JP, LÓPEZ D. 2007. Identificación de amenazas y vulnerabilidades para la elaboración del plan de emergencias del PNN Corales del Rosario y San Bernardo. Universi- 
dad Piloto de Colombia.

[MADS] Ministerio De Ambiente y DesarroLLO SosteniBLE. 2012. Modelo de desarrollo sostenible para el área marina protegida de los archipiélagos de Nuestra Señora del Rosario y de San Bernardo 2013-2040. Colombia.

Maldonado JH, MoReno-SÁnchez RP. 2014. Estimating the adaptive capacity of local communities at marine protected areas in Latin America: a practical approach. Ecol Soc. 19 (1): 16. doi:10.5751/ES-05962-190116

MÁrquez A. 2014. Povos dos recifes: reconfiguracoes na apropiacao social de ecosistemas marinos e litoraneos em duas comunidades do Caribe [tesis doctoral]. Rio de Janeiro: Universidade Federal do Rio de Janeiro.

MCClanahan TR, CinNer JE, Graham NAJ, Daw TM, Maina J, Stead SM, Wamukota A, Brown K, Venus V, Polunin NVC. 2009. Identifying reefs of hope and hopeful actions: contextualizing environmental, ecological, and social parameters to respond effectively to climate change. Conserv Biol. 23 (3): 662671.

McClanahan TR, Cinner JE, Maina J, Graham NAJ, Daw TM, Stead SM, Wamukota A, Brown K, Ateweberhan M, Venus V, PolUNIN NVC. 2008. Conservation action in a changing climate. Conserv Lett. 1: 53-59.

Mendoza S, Moreno-SÁnchez R. 2014. Construcción participativa de un modelo de resiliencia socio ecológica en el territorio de Barú, Bolívar, Colombia. Informe presentado a Colciencias en el marco del proyecto "Apropiación social del conocimiento ecológico con comunidades marino-costeras en áreas marinas protegidas". Grupo de Estudios Ambientales y de los Recursos NaturalesGEMAR, Universidad de los Andes.

MKENDA AF. 2000. The relative welfare of artisan fishermen in Zanzibar. Second International Conference on Environment and Development, the Royal Swedish Academy of Sciences, Stockholm, 6-8 September 2000. http://www.yourk.ac.uk/depts/eeem/publish/e depdf/Confer-2000-117-v2.pdf.

Moreno-SÁnchez RP, Maldonado JH. 2013. Adaptive capacity of fishing communities at marine protected areas: A case study from the Colombian pacific. Ambio. 42 (8): 985-996. doi:10.1007/s13280-013-0454-y

Mujinga W, Lwamba J, Mutala S, Husken SMC. 2009. An inventory of fish species at the urban markets in Lubumbashi, Democratic Republic of Congo. Regional Programme Fisheries and HIV/AIDS in Africa: Investing in Sustainable solutions. The World- Fish Center. Project Report 1983. 30 p.

Nayak PK, Oliveira LE, Berkes F. 2014. Resource degradation, marginalization, and poverty in small-scale fisheries: threats to social-ecological resilience in India and Brazil. Ecol Soc. 19 (2): 73. doi:10.5751/ES06656-190273

[OECD] ORganisation FOR ECONOMIC CO-OPERation and Development. 2016. Pesca y acuicultura en Colombia. Journal of Sea. 1 (Pesca artesanal y acuicultura). 34. [accessed 2021 December]. https://www.oecd.org/tad/fisheries /Fisheries_Colombia_SPA_rev.pdf.

Pineda I, Martínez La, Bedoya D, Caparroso P, RoJAS JA. 2006. Plan de manejo del Parque Nacional Natural Corales del Rosario y San Bernardo. UAESPNN, Territorial Costa Caribe.

Pita C, Villasante S, Pascual J. 2019. Managing small scale Fisheries under data poor scenarios: lessons from around the world. Mar Policy. 101: 154-157.

[PNN] Parques Nacionales Naturales de Colombia. 2019. Plan de manejo Parque Nacional Natural los Corales del Rosario y de San Bernardo (2016-2021). $260 \mathrm{p}$.

[PNN] Parques Nacionales Naturales de Colombia. 2020. Plan de Manejo del Parque Nacional Natural Los Corales del Rosario y de San Bernardo (2020-2025). 228 p.

Rodríguez-SÁnchez CA, MoReno-SÁnchez RP, 
Maldonado JH. 2016. Incidencia de dos medidas diferentes de pobreza en la estimación de la capacidad adaptativa de comunidades locales ubicadas en áreas marinas protegidas: el caso de la comunidad de Barú, Bolívar. Bol Invest Mar Cost. 45 (2): 197-236. doi:10.25268/bimc.invemar.2016.45.2.683

Rueda M, Doncel O, Viloria E, Mármol C, García C, Girón A, García L, Rico F, Rodríguez A, Borda BC. 2011. Atlas de la pesca marino-costera de Colombia: 20102011. Tomo Pacífico. INVEMAR y ANH. Serie de publicaciones del INVEMAR. Santa Marta.

Teh L, Sumaila UR. 2007. Malthusian overfishing in Pulau Banggi? Mar Policy. 31 (4): 451457.

Thorpe A, Neil A, Allison E. 2007. Fisheries and poverty reduction. CAB Reviews: Perspectives in Agriculture, Veterinary Science, Nutrition and Natural Resources. 2 (85): 1-12.

Tietze U, Groenewold G, Marcoux A. 2000. Demographic change in coastal fishing communities and its implications for the coastal environments. FAO Fish Tech Pap. 403.

Villamil E, Bolaño J, Gómez W, Valencia N, Geles M, Moreno-Sánchez R, Mendoza S, MaLdonAdo JH. 2015. El pescador de Barú: una aproximación a la recuperación del conocimiento asociado a la pesca. Universidad de los Andes, Facultad de Economía, CEDE, Ediciones Uniandes.

Viloria HMM, ANTe RF, Pérez PS, Correa MC, JimÉnez LEA, Llano CG, Martínez W, CASTRO A, Posada S, Gómez C, et al. 2014. Caracterización del uso y aprovechamiento de recursos hidrobiológicos en áreas protegidas de parques nacionales naturales en el caribe de Colombia. Bol Invest Mar Cost. 43 (2): 277306.

WiLlmann R. 2004. Poverty in coastal fisheries. In: NeILAND AE, BÉNÉ C, editors. Poverty and small-scale fisheries in West Africa. Dordrecht: Kluwer Academic Publishers. p. 245251.

World BANK. 2020. The World Bank Data. https://data.worldbank.org/indicator/SP.POP. DPND. 